\title{
Properties of Cavity Walls
}

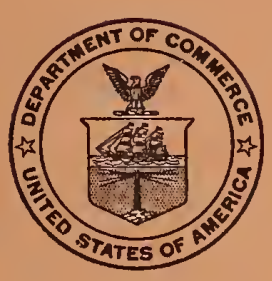

United States Department of Commerce National Bureau of Standards Building Materials and Structures Report 136 


\section{BUILDING MATERIALS AND STRUCTURES REPORTS}

On request, the Superintendent of Documents, U. S. Government Printing Office, Washington 25 , D. C., will place your name on a special mailing list to receive notices of new reports in this series as soon as they are issued. There will be no charge for receiving such notices.

If 100 copies or more of any report are ordered at one time, a discount of 25 percent is allowed. Send all orders and remittances to the Superintendent of Documents, U. S. Government Printing Office, Washington $25, D$. C.

The following publications in this series are available by purchase from the Superintendent of Documents at the prices indicated:

BMS1

BMS2

BMS3

BMS4

BMS5

BMS6

BMS7

BMS8

BMS9

BMS10

BMS11

BMS12

BMS13

BMS14

BMS15

BMS16

BMS17

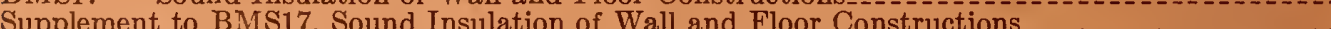
plement to BMS17, Sound Insulation of Wall and Floor Constructions BMS18 Structural Properties of "Pre-fab" Constructions for Walls, Partitions, and Floors Sponsored by the Harnischfeger Corporation

BMS19

BMS20

BMS21

BMS22

BMS23

BMS24

BMS25

BMS26

BMS27

BMS28

BMS29

BMS30

BMS31

BMS32

BMS34

BMS36

BMS38

Research on Building Materials and Structures for Use in Low-Cost Housing - ..-...Methods of Determining the Structural Properties of Low-Cost House Constructions.Suitability of Fiber Insulating Lath as a Plaster Base

Accelerated Aging of Fiber Building Boards

Survey of Roofing Materials in the Southeastern States

Water Permeability of Masonry Walls

Methods of Investigation of Surface Treatment for Corrosion Protection of Steel

Structural Properties of the Insulated Steel Construction Co.'s "Frameless-Steel" Constructions for Walls, Partitions, Floors, and Roofs

sored by the H. H. Robertson Co
Structural Properties of the Curren Fabrihome Corporation's "Fabrihome" Constructions for Walls and Partitions.

Structural Properties of "Steelox" Constructions for Walls, Partitions, Floors, and Roofs, Sponsored by Steel Building, Inc _..

Properties of Some Fiber Building Boards of Current Manufacture.

Indentation and Recovery of Low-Cost Floor Coverings- Structural Properties of "Wheeling Long-Span Steel Floor" Construction Sponsored by the Wheeling Corrugating Co

Structural Properties of a "Tilecrete" Floor Construction Sponsored by Tilecrete

Floors, Inc paration and Revision of Building Codes by Connecticut Pre-Cast Buildings Corporation tructural Properties of a Concrete-Block Cavity-Wall Construction Sponsored by the

National Concrete Masonry Association
Structural Properties of "Dun-Ti-Stone" Wall Construction Sponsored by the W. E. Dunn Manufacturing Co

Structural Properties of a Brick Cavity-Wall Construction Sponsored by the Brick Manufacturers Association of New York, Inc.

Structural Properties of a Reinforced-Brick Wall Construction and a Brick-Tile CavityWall Construction Sponsored by the Structural Clay Products Institute....... Structural Properties of Conventional Wood-Frame Constructions for Walls, Partitions, Floors, and Roofs

Structural Properties of "Nelson Pre-Cast Concrete Foundation" Wall Construction Sponsored by the Nelson Cement Stone Co., Inc Structural Properties of "Bender Steel Home" "Wall Construction Sponsored by the Bender Body $\mathrm{Co}$

Backflow Prevention in Over-Rim Water Supplies

Survey of Roofing Materials in the Northeastern States.

Structural Properties of a Wood-Frame Wall Construction Sponsored by the Douglas Fir Plywood Association

Structural Properties of "Insulite" Wall and "Insulite" Partition Constructions Sponsored by the Insulite Co Structural Properties of Two Brick-Concrete-Block Wall Constructions and a ConcreteWall Construction Sponsored by the National Concrete Masonry Assoc....... Performance Test of Floor Coverings for Use in Low-Cost Housing: Part 1- 1 . W
Structural Properties of Wood-Frame Wall, Partition, Floor, and Roof Constructions With "Red Stripe" Lath Sponsored by the Weston Paper and Manufacturing Co... Structural Properties of Two "Dunstone" Wall Constructions Sponsored by the W. E. Dunn Manufacturing Co.

- Out of print.

†Superseded by BMS116. 


\title{
Properties of Cavity Walls
}

\author{
Daniel S. Goalwin
}

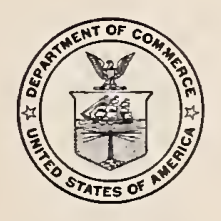

Building Materials and Structures Report 136 Issued May 20, 1953 


\section{Contents}

1. Introduction

2. Cavity-wall design

3. Materials

4. Construction of walls

4.1. Workmanship

4.2. Construction details

5. Structural properties

5.1. Compressive load

5.2. Transverse load

5.3. Concentrated load

5.4. Impact load

5.5. Racking load

6. Water permeability

Method testing

6.2. Test results

7. Heat transfer

7.1. Test equipment and procedure

7.2. Test results

8. Fire resistance

8.1. Test specimens _..._.

8.2. Test results

9. Discussion and summary

10. References 


\title{
Properties of Cavity Walls
}

Daniel S. Goalwin

\begin{abstract}
A compilation is given of data on the performance characteristics of cavity walls, including previously published and some hitherto unplublished inaterial. Structural tests were conducted on eavity walls of brick, concrete block, and structural clay tile. Other tests were made on the properties of wall ties, rain penetrability, thermal transinittance, and fire resistance.

Under certain conditions of loading, compressive strength, resistance to concentrated load, racking load, and impact strength were found to be roughly equivalent to those of conventional walls using the same quantity and quality of material. With respect to resistence to transverse load, the cavity walls were somewhat inferior. When properly flaslied and with suitable weep holes, the cavity walls had satisfactory resistance to rain penetration. Their thermal transmittance was about 25 percent lower than for similar solid walls. Their resistance to the effect of fire was satisfactory provided certain limiting loading conditions were met.
\end{abstract}

\section{Introduction}

A cavity wall is a form of masonry wall construction consisting of two parallel wythes ${ }^{1}$ of masonry separated by a continuous air space, or carity, usually about $2 \mathrm{in}$. wide. It is a type of construction that has been widely used in Great Britain for many rears, and which in recent rears has come into greater use in this country. Carity walls may be constructed of rarious combinations and thicknesses of brick, stone, structural clay tile, concrete masonry, concrete, etc.

One of the adrantages claimed for the cavitywall construction is that the air space acts to prerent rain or moisture that has seeped through the outer wrthe from penetrating the inner wrthe. In addition, the carity interrupts the continuity of the masonry and provides the additional insulating effect of an air space. These adrantages may be lost by improper design of cavity walls, particularly with respect to such items as flashings, openings, ties, and wall intersections, or lack of care in construction.

Common practice at present is to distinguish between hollow and carity walls. Hollow walls are walls that contain masomry bonds or bridges; these mar permit the passage of water between the faces of the walls. In properly built carity walls, there is no masonry bridge permitted between the outer and interior wrthes, the two tiers being bonded br means of metallic or other nommasonry ties to maintain a substantially constant carity width. These ties are usually rods or wires bent into $Z$ or rectangular shapes, affording anchorage by embedment of the ends in mortar joints.

Water that penetrates the outer leaf of a cavity wall seeps down its inner face and is direrted outward by means of flashings, generally placed near

"The terms "wythe" and "leaf" are used interchangeably. the bottom of the cavity and abore windows and other openings, allowing the water to pass through weep holes in the outer face. These holes, while necessary to dispose of water, should be kept small so as to exclude rodents and to prevent any substantial circulation of air in the cavit. sequent increase in thermal transmittance.

Tests of structural properties, fire resistance, heat transfer, and water resistance of carity walls have been made at the National Bureau of Standards; most of these tests have been described in reports of the Building Materials and Structures series. It is the purpose of this report to collect both previously published and hitherto umpublished data so as to summarize in one report information on cavity walls required for building design, construction, and code proparation.

\section{Cavity-Wall Design}

Design criteria for carity walls may be found in various reference works, including those of Fitzmaurice, "Principles of Modern Building" [1]," Plummer, "Brick and 'Tile Engineering" [2], and "Tile Engineering" [3]. Design of the walls tested followed closely the general requirements for carit r walls of the "American Standard Building Code Requirements for Masonry" [4], which is now in the process of revision. Sound engineering practice requires that the compressire stresses in carity walls shall not exceed those giren in table 1 . These compressive stresses are based upon the gross cross-sectional area of the wall, minus the area of the cavity between the wrtles, with the assumption that the floor loads bear on but one of the two wrthes. When such walls are loaded unifor'mls at the center of the wall, the allowable

2 Figures in brackets indicate the literature references at the end of this paper. 
stresses may be increased by 25 percent. When anticipated wind pressures exceed $20 \mathrm{lb} / \mathrm{ft}^{2}$, type $B$ mortar should not be used on cavity walls of 12-in. thickness or less.

TABLE 1. Maximum loading for masonry cavity walls

\begin{tabular}{|c|c|c|}
\hline \multirow{2}{*}{ Material } & \multicolumn{2}{|c|}{$\begin{array}{l}\text { Allowable eompressive } \\
\text { stress (on gross less eav- } \\
\text { ity area, load bearing on } \\
\text { only one wy the). }\end{array}$} \\
\hline & $\begin{array}{l}\text { Type A-1 } \\
\text { mortar }^{1}\end{array}$ & $\begin{array}{l}\text { Type B } \\
\text { mortar } 1\end{array}$ \\
\hline $\begin{array}{l}\text { Solid masonry units: } \\
\text { Strength greater tban } 2,500 \mathrm{lb} / \mathrm{in}^{2} \\
\text { Strength } 1,500 \text { to } 2,500 \mathrm{lb} / \mathrm{in} .^{2}-\ldots \\
\text { Hollow masonry units }\end{array}$ & $\begin{array}{c}l b / \text { in }^{2} \\
140 \\
100 \\
70\end{array}$ & $\begin{array}{c}2 b_{1}^{\prime i n} .^{2} \\
110 \\
80 \\
55\end{array}$ \\
\hline
\end{tabular}

1 The mortar designations used in this paper are similar to those in the tentatire ASTM Speeifications for Mortar for Unit Masonry [7]. Mortar $\Lambda-1$ is defined as consisting of 1 part of portland eement by volume, 1/4 part of hydrated lime or lime putty, and aggregate in amount not less than $21_{4}$ no more than 3 times the sum of the rolumes of the eement and lime used. Mortar $B$ eonsists of 1 part of portland eement by volume, not less than $1 / 2$ nor more than 11 parts of hydrated lime or lime putty, and aggregate in amount not less than 21/4 nor more tban 3 times the sum of the volumes of tbe eement not less than 2 .

and lime used. in. eubes of the nortar at 28 days be not less tban $2,500 \mathrm{lb} / \mathrm{in} .^{2}$ for type A-1 and $750 \mathrm{lb} / \mathrm{in}^{2}$ for type $\mathrm{B}$.

Cavity walls should not exceed $35 \mathrm{ft}$ in height, except that 10 -in. cavity walls should not exceed 25 $\mathrm{ft}$ in height above their support. As cavity-wall floor loads are usually carried by the inner wythe, the outer wythe is customarily $4 \mathrm{in}$. in nominal thickness, and the thickness of the inner tier is increased if needed for high walls or to support heavy loads. A nominal 10 -in. cavity wall consists of two nominal 4 -in. leaves and a 2 -in. cavity; a nominal 14-in. cavity wall consists of a 4-in. outer leaf, a 2 -in. cavity, and an 8 -in. inner leaf.

The facing and backing of cavity walls should be bonded with 3/16-in.-diameter steel rods or metal ties of equivalent thickness embedded in the horizontal joints. The ties shall be spaced uniformly to provide at least one per $4 \frac{1}{2} \mathrm{sq}$ ft of wall surface; the distance between adjacent ties should not exceed $26 \mathrm{in.}$ Rods bent to rectangular shape should be used with hollow masonry units laid with cells vertical; in other walls the ends of the ties should be bent to 90 -degree angles to provide hooks not less than 2 in. long. Additional bonding ties should be provided at all openings, spaced not more than $3 \mathrm{ft}$ apart around the perimeter and within $12 \mathrm{in}$. of the opening. Ties should be of corrosion-resistant metal or coated with a corrosion-resistant metal or other approved protective coating.

British specifications [5] require that steel wall ties be coated with zinc. They also require a crimp or dip in the ties so as to prevent water traveling across the tie to the inner wythe. If no crimp is used, the tie should be inclined downward to the outer wythe.

Because one of the purposes of the cavity is to provide a barrier against the penetration of moisture, it is essential to provide flashing wherever the cavity has been bridged for any purpose, such as heads and jambs of openings, joist bearing points, etc.

Proper drainage should be provided at the base of the cavity to dispose of any water that might penetrate into the cavity. "This may be accomplished by providing weep holes in the vertical joints of the course of masonry of the outer tier immediately above a flashing. The cavity must be kept clear of mortar droppings so that the weep holes are not obstructed and so that moisture cannot be transmitted across the cavity on a bridging of mortar.

\section{Materials}

Tests were conducted at the National Bureau of Standards BMS101 [6] on the strength of wall ties under axial, tensile, and compressive load, and on the corrosion resistance of steel ties coated with various materials.

Table 2 lists the basic dimensions of some of the ties, partial results of compressive tests on tie assemblies, and which tie types were used in wall specimens for other tests described later in this report. Some of the ties are shown in figure 1. Outdoor-weathering specimens are shown in. figure 2.

The tensile specimens failed by pulling out of the tie, by tension failure in the tie, or by crushing of the mortar under the tie, with subsequent splitting of the brick-mortar assembly. Partial bond failure of the tie occurred in many specimens that failed in tension or by crushing of the mortar, the ends of the ties often having slipped in the bed as much as $1 / 8$ in. The compressive-strength specimens failed either by buckling of the ties or

TABLE 2. Properties of typical wall ties

\begin{tabular}{|c|c|c|c|c|c|c|c|}
\hline \multirow{2}{*}{ Kind of material } & \multicolumn{3}{|c|}{ Over-all dimensions } & \multirow{2}{*}{ Shape } & \multicolumn{2}{|c|}{$\begin{array}{l}\text { Maximum compres- } \\
\text { sive load }{ }^{1}\end{array}$} & \multirow{2}{*}{ Used in walls } \\
\hline & Length & Width & Thiekness & & $\begin{array}{c}\text { Mortar } \\
\mathbf{A}-1\end{array}$ & $\underset{B}{\operatorname{Mort}} \mathrm{r}$ & \\
\hline $\begin{array}{l}\text { Copperweld } \\
\text { Steel } 2 \\
\text { Do. }{ }^{2} \\
\text { Do, } \\
\text { Do. } \\
\text { Do }\end{array}$ & in. $\begin{array}{r}6 \\
6 \\
6 \\
6 \\
6 \\
6\end{array}$ & in. $\begin{array}{r}6 \\
6 \\
6 \\
4 \\
6 \\
4\end{array}$ & $\begin{array}{r}\text { in. } \\
0.027 \\
.188 \\
.131 \\
.158 \\
.188 \\
.250\end{array}$ & $\begin{array}{l}\text { Z-shape } \\
\text { Redo do } \\
\text { Reetangular } \\
\text { Z-shape } \\
\text { Rectangular- }\end{array}$ & $\begin{array}{l}l b . \\
3,880 \\
2,025 \\
600 \\
2,310 \\
---.-\end{array}$ & $\begin{array}{r}l 6 . \\
2,180 \\
1.810 \\
520 \\
2,060 \\
\end{array}$ & $\begin{array}{l}\mathrm{IC}, 2 \mathrm{~A}, 2 \mathrm{~B}, 2 \mathrm{C}, 2 \mathrm{D}, 2 \mathrm{E}, 3 \mathrm{~A}, 3 \mathrm{~B}, 3 \mathrm{C}, 3 \mathrm{D} . \\
1 \mathrm{~A}, 1 \mathrm{~B}, 1 \mathrm{D}, 1 \mathrm{E} .\end{array}$ \\
\hline
\end{tabular}

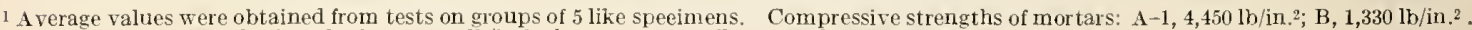

2 Average yield strength of steel wires $86,000 \mathrm{lb} / \mathrm{in}^{2}$, the average tensile strength $90,000 \mathrm{lb} / \mathrm{in} .{ }^{2}$. 


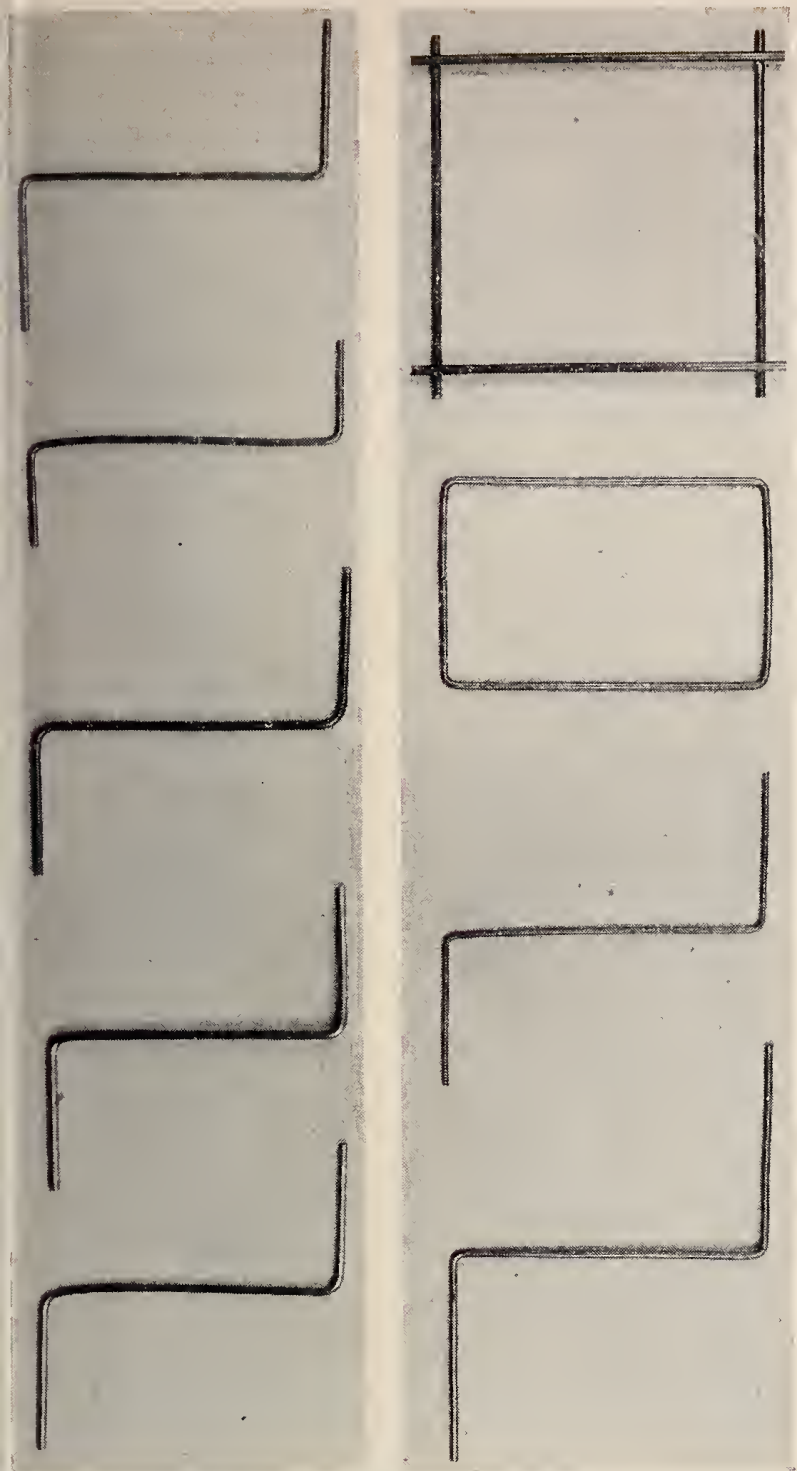

Figdre 1. Typical cavity wall ties.

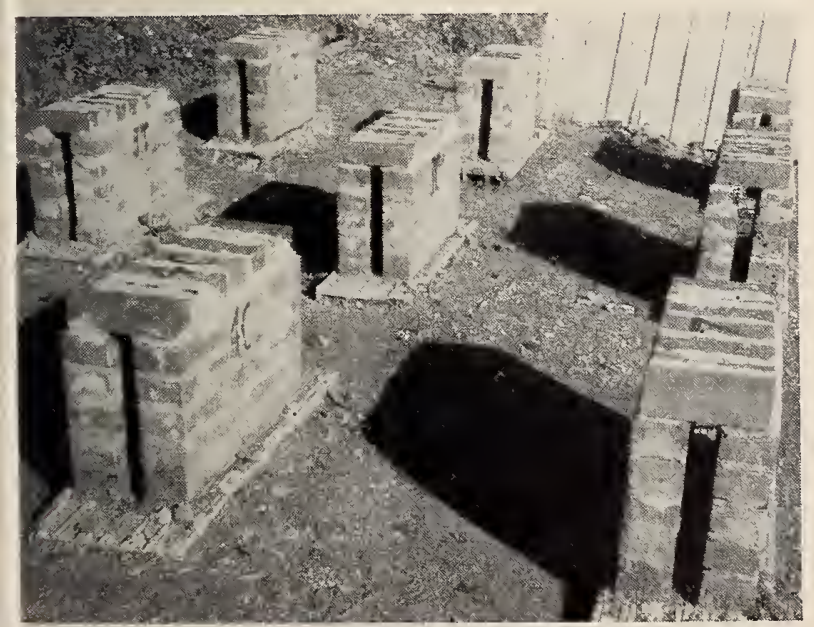

FIGURE 2. Specimens for outdoor weathering of ties. by erushing of the mortar against the ends of the ties.

Uneoated steel ties and those roated with neat cement or mortar were lightly rusted in 10 days or less of indoor (accelerated) weathering, and most were severely rusted in 30 days. Cementitious coatings did not retard rust formation and even appeared to have had an accelerating effect. Coatings of coal-tar paint afforded some protection, but within 120 days the ties were severely rusted adjacent to the masonry. It is possible that the coatings at these points were nicked with the trowel when the mortar protruding from the joints was cut away. The copper coatings on the copperweld ties were darkened by the exposure, but no evidence of rusting of the steel beneath the copper was noted.

Uncoated steel ties corroded in less time when exposed to outdoor than to indoor (accelerated) weathering. The cementitious coatings seemed to offer better protection to the ties when exposed outdoors than indoors. Ties coated with paint were moderately rusted at points adjacent to the inner faces of the masonry after 180 days of exposure.

Physical properties of the concrete blocks, brick, and tile used in tests described later in this report are listed in table 3 . Details of the con-
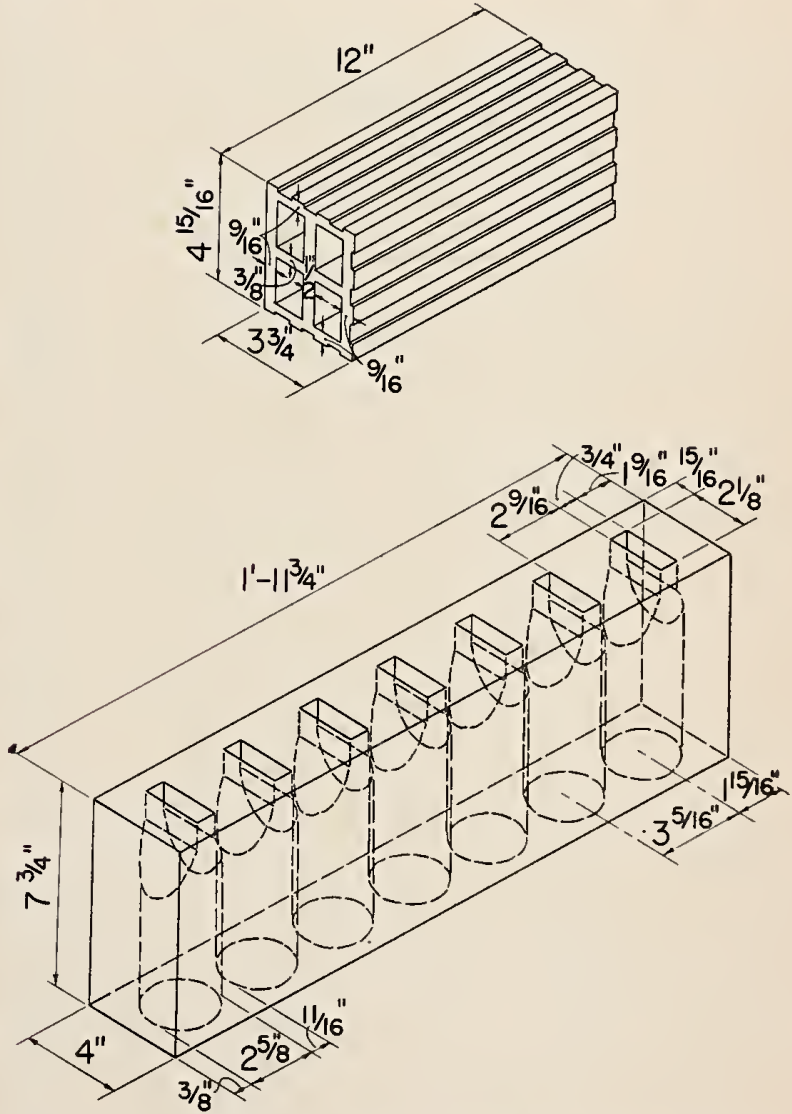

Figure 3. Details of concrete-block and structural clay tile.

The above include all test specimens except those used in fire-endurance tests. 


\begin{tabular}{|c|c|c|c|c|c|c|c|c|c|c|}
\hline \multicolumn{11}{|c|}{ Concrete blocks } \\
\hline \multirow{2}{*}{ Used in walls } & \multirow{2}{*}{ Dimensions } & \multirow{2}{*}{$\begin{array}{c}\text { Dry } \\
\text { weight }\end{array}$} & \multirow{2}{*}{\multicolumn{3}{|c|}{ Aggregate }} & \multirow{2}{*}{\multicolumn{2}{|c|}{$\begin{array}{l}\text { Density } \\
\text { of } \\
\text { concrete }\end{array}$}} & \multicolumn{2}{|c|}{$\begin{array}{l}\text { Water absorption (24- } \\
\text { hour cold immersion) }\end{array}$} & \multirow{2}{*}{$\begin{array}{l}\text { Compressive } \\
\text { strength } \\
\text { (gross area) }\end{array}$} \\
\hline & & & & & & & & $\begin{array}{c}\text { By } \\
\text { weight }\end{array}$ & $\begin{array}{l}\text { By volume } \\
\text { of concrete }\end{array}$ & \\
\hline $\begin{array}{l}1 \mathrm{~A}, 1 \mathrm{~B}, 1 \mathrm{C}, 1 \mathrm{D}, \text { parts } 1 \mathrm{E}-1,1 \mathrm{E}-2 \\
\text { Part } 1 \mathrm{E}-1 \\
\text { Part } 1 \mathrm{E}-2\end{array}$ & $\begin{array}{l}\text { in. } \\
4.0 \text { by } 23.8 \text { by } 7.9 \\
4.0 \text { by } 23.8 \text { by } 7.9 \\
4.0 \text { by } 23.8 \text { by } 7.9\end{array}$ & $\begin{array}{l}\text { lb/block } \\
22 \\
31 \\
33\end{array}$ & \multicolumn{3}{|c|}{$\begin{array}{l}\text { Cinders } \\
\text { Expanded slag...- } \\
\text { Sand and gravel..- }\end{array}$} & \multicolumn{2}{|c|}{$\begin{array}{l}l b / f t^{3} \\
88 \\
108 \\
130\end{array}$} & $\begin{array}{l}\text { Percent } \\
14.4 \\
10.2 \\
6.5\end{array}$ & $\begin{array}{r}l b / f t^{3} \\
12.7 \\
11.1 \\
8.4\end{array}$ & $\begin{array}{l}\text { lb/in. } .^{2} \\
900 \\
895 \\
860\end{array}$ \\
\hline \multicolumn{11}{|c|}{ Brick } \\
\hline \multirow{2}{*}{ Used in walls } & \multirow{2}{*}{ Dimensions } & \multirow{2}{*}{$\begin{array}{l}\text { Dry } \\
\text { weight }\end{array}$} & \multicolumn{6}{|c|}{ Water absorption } & \multirow{2}{*}{$\begin{array}{l}\text { Modulus } \\
\text { of } \\
\text { rupture }\end{array}$} & \multirow{2}{*}{$\begin{array}{l}\text { Compressive } \\
\text { strength }\end{array}$} \\
\hline & & & \multicolumn{2}{|c|}{ 5-hour boil } & \multicolumn{2}{|c|}{$\begin{array}{l}\text { Saturation } \\
\text { coefficient }\end{array}$} & \multicolumn{2}{|c|}{$\begin{array}{l}\text { Initial rate } \\
\text { of absorption }{ }^{2}\end{array}$} & & \\
\hline $\begin{array}{l}2 \mathrm{~A}, 2 \mathrm{~B}, 2 \mathrm{C}, 2 \mathrm{D} \\
3 \mathrm{~A}, 3 \mathrm{~B}, 3 \mathrm{C}, 3 \mathrm{D} \\
2 \mathrm{E}\end{array}$ & $\begin{array}{l}i n . \\
8.1 \text { by } 3.6 \text { by } 2.3 \\
8.0 \text { by } 3.8 \text { by } 2.3 \\
8.0 \text { by } 3.6 \text { by } 2.2\end{array}$ & $\begin{array}{l}\text { lb/brick } \\
4.1 \\
4.8 \\
\end{array}$ & \multicolumn{2}{|l|}{$\begin{array}{l}\text { Percent } \\
18.7 \\
14.7 \\
20.0\end{array}$} & \multicolumn{2}{|c|}{$\begin{array}{r}0.74 \\
.69 \\
.79\end{array}$} & \multicolumn{2}{|r|}{$\begin{array}{l}0 z \\
1.5 \\
1.4\end{array}$} & $\begin{array}{l}\text { lb/in.2 } \\
540 \\
830 \\
450\end{array}$ & $\begin{array}{l}\text { lb/in.2 } \\
3,240 \\
5,160 \\
3,580\end{array}$ \\
\hline \multicolumn{11}{|c|}{ Tile } \\
\hline Used in walls & Dimensions & $\begin{array}{l}\text { Dry } \\
\text { weight }\end{array}$ & $\begin{array}{l}\text { Cells } \\
\text { per } \\
\text { tile }\end{array}$ & & $\begin{array}{l}\text { ackness } \\
\text { ace shell } \\
\text { ninimum }\end{array}$ & & $\begin{array}{l}\text { Ratio } \\
\text { of } c \\
\text { thick } \\
\text { bearir }\end{array}$ & $\begin{array}{l}\text { width } \\
\text { ell to } \\
\text { ness of } \\
\text { ig shell }\end{array}$ & $\begin{array}{l}\text { Water } \\
\text { absorption } \\
\text { (1-hr boil) }\end{array}$ & $\begin{array}{l}\text { Compressive } \\
\text { strength } \\
\text { (load applied } \\
\text { to side) }\end{array}$ \\
\hline $\begin{array}{l}3 \mathrm{~A}, 3 \mathrm{~B}, 3 \mathrm{D} \\
4 \mathrm{~A}-1 \\
4 \mathrm{~A}-2\end{array}$ & $\begin{array}{l}i n . \\
3.8 \text { by } 4.9 \text { by } 12.0 . \\
3.8 \text { by } 12.0 \text { by } 12.0 \\
3.8 \text { by } 5.0 \text { by } 12.0\end{array}$ & $\begin{array}{r}\text { lb/tile } \\
9.5 \\
17.2 \\
8.6\end{array}$ & $\begin{array}{l}4 \\
3 \\
2\end{array}$ & & $\begin{array}{r}\text { in. } \\
0.4 \\
.5 \\
.5\end{array}$ & & 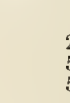 & $\frac{2}{5}$ & $\begin{array}{l}\text { Percent } \\
5.9 \\
10.2 \\
10.7\end{array}$ & $\begin{array}{r}l b / i n .^{2} \\
1,720 \\
1,040 \\
860\end{array}$ \\
\hline
\end{tabular}

124 -hr cold $\div 5$-hr boil.

2 Gain in weight of dry brick ( 30 in. $^{2}$ ) in contact with 18 in. of water for 1 minute.

crete block and structural clay tile (except the tile used for fire-endurance tests) are shown in figure 3. The blocks were laid with the cells vertical.

Only cement-lime mortars were used in the constructions described in this report. Definitions of the classes of mortar are taken from the ASTM Tentative Specifications for Mortar for Unit Masonry, C270-51 T [7], and are given in table 1. Mortar $B$ is the familiar 1:1:6 by volume. The amount of water added to the mortar was in each case adjusted to the satisfaction of the mason.

\section{Construction of Walls}

\subsection{Workmanship}

The walls tested fall into two general classes with respect to workmanship. Workmanship A was superior to the commercial workmanship designated as workmanship B. In workmanship A, the head or cross joints were filled solidly. In workmanship B, the mortar was applied only to the outer edges of the head or cross joints. In both workmanships, a wood strip was placed on the ties to prevent mortar droppings from fouling the ties or the weep holes.

The effect of workmanship on compressive strength of brick walls other than cavity walls is discussed in "Compressive Strength of Clay
Brick Walls" [8] and on transverse strength and water permeability in "Watertightness and Transverse Strength of Masonry Walls" [9].

\subsection{Construction Details}

Four wall types have been tested at the National Bureau of Standards, concrete-block walls, allbrick walls, walls with brick facing and clay-tile backing, and walls with structural clay tile for both facing and backing.

Details of construction, including size, mortar, and workmanship, are given in table 4 . A bricktile wall under construction is shown in figure 4 .

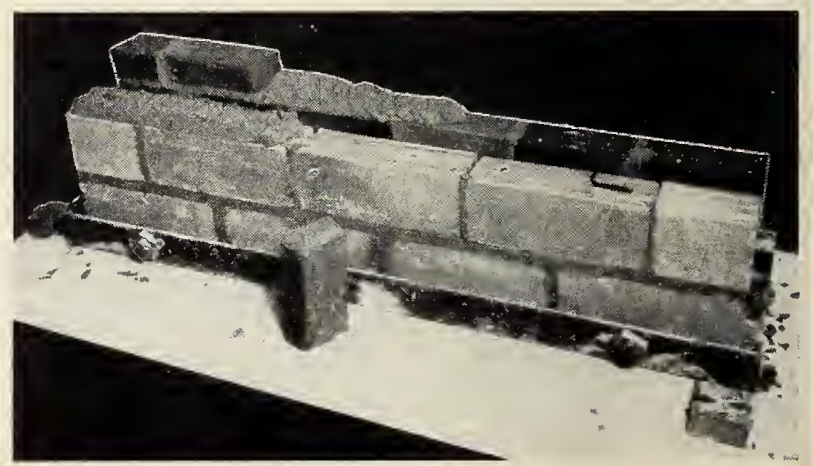

FIgURE 4. A brick-tile cavity wall under construction for use in structural tests. 
TABLE 4. Construction details of the test walls

\begin{tabular}{|c|c|c|c|c|c|c|c|c|c|}
\hline \multirow{2}{*}{ Wall No. } & \multirow{2}{*}{ Type of wall } & \multirow{2}{*}{ Type of tests } & \multicolumn{2}{|r|}{ Reference } & \multicolumn{3}{|c|}{ Nominal sizes of walls } & \multirow{2}{*}{ Mortar 1} & \multirow{2}{*}{$\begin{array}{l}\text { Workman- } \\
\text { ship, ? }\end{array}$} \\
\hline & & & Report & Wall designation & Width & Height & Thickness & & \\
\hline $1 A_{---}$ & Cinder-concrete & Compressive, transverse, & BMS21 & $\mathrm{AX}-\mathrm{C}, \mathrm{\Lambda X}-\mathrm{T}, \mathrm{AX}-\mathrm{I}$ & ${ }^{f t}{ }_{4}$ & ${ }^{f t}{ }_{8}$ & ${ }^{i n}{ }_{10}$ & $\Lambda-1$ & B. \\
\hline $1 \mathrm{~B}$ & $\begin{array}{l}\text { block, } \\
\text { do }\end{array}$ & $\begin{array}{l}\text { lmpact. } \\
\text { Racking }\end{array}$ & BMS21 & $A X-R \ldots$ & 8 & $x$ & 10 & $\Lambda-1$ & 13. \\
\hline 1C- & - do & Water permeability & BMS82 & B123 & 3 & 4 & 10 & $A-1$ & $B$. \\
\hline 1D & do & Heat transfer & (3) & $\mathrm{H}^{\mathrm{T}} \mathrm{T}-47$ & 5 & 8 & $10^{3 / 4}$ & $A-1$ & $B$. \\
\hline $\begin{array}{l}1 \mathrm{E}-1-\ldots \\
1 \mathrm{E}-2-\ldots\end{array}$ & $\begin{array}{l}\text { Concrete block } \\
\text { do }\end{array}$ & Fire resistance & BMS117 & $\begin{array}{l}12 \\
3\end{array}$ & 16 & 11 & 10 & & B. \\
\hline $1 \mathrm{E}-2 .--$ & - & 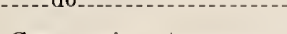 & BMS120 & DD & 16 & 11 & 10 & & B. \\
\hline $2 A_{--}$ & Brick-......- & $\begin{array}{l}\text { Compressive, transverse, } \\
\text { impact. }\end{array}$ & BMS23 & $\mathrm{BD}-\mathrm{C}, \mathrm{BD}-\mathrm{T}, \mathrm{BD}-\mathrm{I}$ & 4 & 8 & $93 / 8$ & B. & A. \\
\hline & -...-do do & Racking & BMS23 & BD-R & 8 & 8 & $93 / 8$ & $B$ & $\Lambda$. \\
\hline $\begin{array}{l}2 \mathrm{C}-- \\
2 \mathrm{D}-\mathrm{S}_{-}-\end{array}$ & Brick (solid) & $\begin{array}{l}\text { Water permeability } \\
\text { Heat transfer }\end{array}$ & $\underset{(3)}{\mathrm{BMS} 82_{--}}$ & $\begin{array}{l}\text { B169-- } \\
\text { HT-23- }\end{array}$ & $\begin{array}{l}3 \\
5\end{array}$ & $\begin{array}{l}4 \\
8\end{array}$ & $93 / 8$ & B & $\Lambda$. \\
\hline $2 \mathrm{D}$ & Brick....... & do & (3) & HT-24 & 5 & 8 & $93 / 6$ & 13 & $\Lambda$. \\
\hline $2 \mathrm{E}_{-}$ & --..-do do--.. & Fire resistance & (3) & $74,75,76 \ldots \ldots$ & 16 & 10 & $91 / 4$ & B. & \\
\hline $3 A \ldots$ & Brick-tile ${ }^{6}$ & Compressive, transverse, & BMS24 & $A U-C, A U-T, A U-I$. & 4 & 8 & $93 / 4$ & $\mathbf{B}_{\ldots}$ & A (brick), B \\
\hline $3 B_{--}$ & . do 6 & Racking & BMS24 & A U-R & 8 & 8 & $93 / 4$ & B... & A (brick), B \\
\hline $3 \mathrm{C}_{-}$ & $\ldots$ do ${ }^{6}-\ldots$ & Water permeability & BMS82 & $\mathrm{B} 124, \mathrm{~B} 271, \mathrm{~B} 272 \ldots$ & 3 & 4 & $93 / 4$ & B... & $A$ (brick), B \\
\hline $3 \mathrm{D}_{-}$ & do ${ }^{6} \ldots$ & Heat transfer & (3) & None & 5 & 8 & $93 / 4$ & B... & A (brick), 1 \\
\hline $4 A_{-}$ & Hollow tile_-....... & Fire resistance & RP37 & $110,111 \ldots$ & 8 & 10 & 10 & (?) & B. \\
\hline
\end{tabular}

1 Definitions of mortars given in table 1. Mortar B was 1:1:6 by volume. Mortar A-1 strengtb at 28 days exceeded 2500 lb/in.2. Mortar B strength at 28 days exceeded $750 \mathrm{lb} / \mathrm{in} .^{2}$.

2 Workmanship A was superior, bead joints filled. Workmanship B was commercial, head joints buttered at tbe edges only.

3 From unpublished data.

This wall was divided into two 8-by 11-ft sections; one section of cinder units, one section of sand and gravel units.

3 This wall was divided into two 8-by 11 -ft sections; one section of cinder units, one section of foamed-slag units.

6 Brick facing, tile backing.

i $1: 1: 4$ by volume. Strength at 60 days, $1,065 \mathrm{lb} / \mathrm{in} .^{2}$

The concrete-block walls tested for fire endurance consisted of two 8- by $11-\mathrm{ft}$ sections each, separated by a $3 / 4-$ in. air space, with blocks having different aggregates in each section. The units of one section of wall $1 \mathrm{E}-1$ contained cinder aggregates, the other sand and gravel aggregates; one section of wall 1E-2 also contained cinder aggregates, the other foamed-slag aggregates.

For the walls used in the heat-transfer tests, the edges of the cavity were closed by strips of lumber and plastered over with mortar.

No finish was applied to the faces of any of the walls used in the structural or rain-penetrability tests. The concrete-block wall 1D tested for thermal transmittance had two coats of portland cement-base paint on the outside face and three coats of plaster applied directly over the inside face of the concrete blocks. The two structural clay-tile walls, $4 \mathrm{~A}$ and $4 \mathrm{~B}$, tested for fire resistance, had $3 / 4$ in. of gypsum plaster on the exposed face and 1:3 portland-cement plaster plus 15 percent of lime on the unexposed face.

Ties were placed approximately 24 in. apart on horizontal centers in alternate bed joints for the concrete-block walls used in the structural, rain penetration, and fire-endurance tests, and in every third joint for the cinder-concrete block wall, 1D, used in the heat-transfer tests. They were placed in every sixth brick course for the brick and brick-tile walls.

\section{Structural Properties}

The kinds of loads encountered on exterior walls and a detailed analysis of engineering

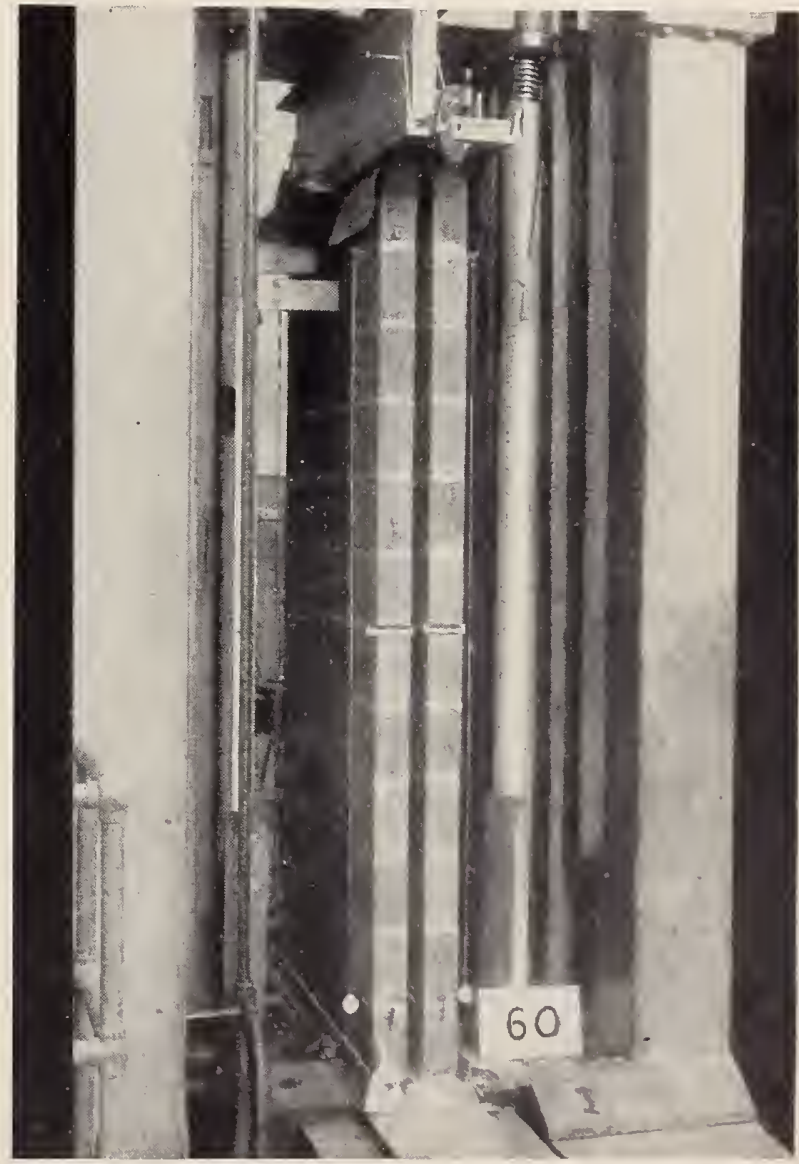

FIGURE 5. Concrete-block cavity wall under compressiveload. Load was applied tbrough a round steel bar abore beam (not visible). 
principles for the design of small houses are discussed in BMS109 [10].

Three types of cavity walls were subjected to compressive, transverse, concentrated, impact, and racking loads at the National Bureau of Standards in accordance with the procedures and methods outlined in ASTM Standard E72-47T and given in BMS2 [11]; these tests are described in detail in BMS21 [12], BMS23 [13], and BMS24 [14]. At least three wall specimens were included in each test group. In general, test procedure was to apply the load in increments, recording the deflection, then release the load and record the set.

\subsection{Compressive Load}

With one exception, compressive loads were applied to a steel plate covering the upper end of the specimen. The load was applied uniformly along a line parallel to the inside face and onethird the thickness of the specimen from the inside face. For one set of tests on a brick cavity wall, $2 \mathrm{~A}$, the load was applied to one wythe only.

A wall under compressive load is shown in figure 5 ; data obtained from the compressive-load tests are listed in table 5 and presented graphically in figures 6 and 7 .

Failure of the concrete-block cavity walls occurred by crushing of the blocks in the back wythe in one or more courses near the top of each of the specimens. Two of the brick cavity walls failed by crushing of the brick and mortar-bed joints in two or three courses of the back wythe at about two-thirds the height, followed by rupture of both backing and face tiers at this height; one specimen failed by crushing of a few bricks and a mortar bed

\section{TABLE 5. Results of structural tests}

Figures are averages for three specimens.

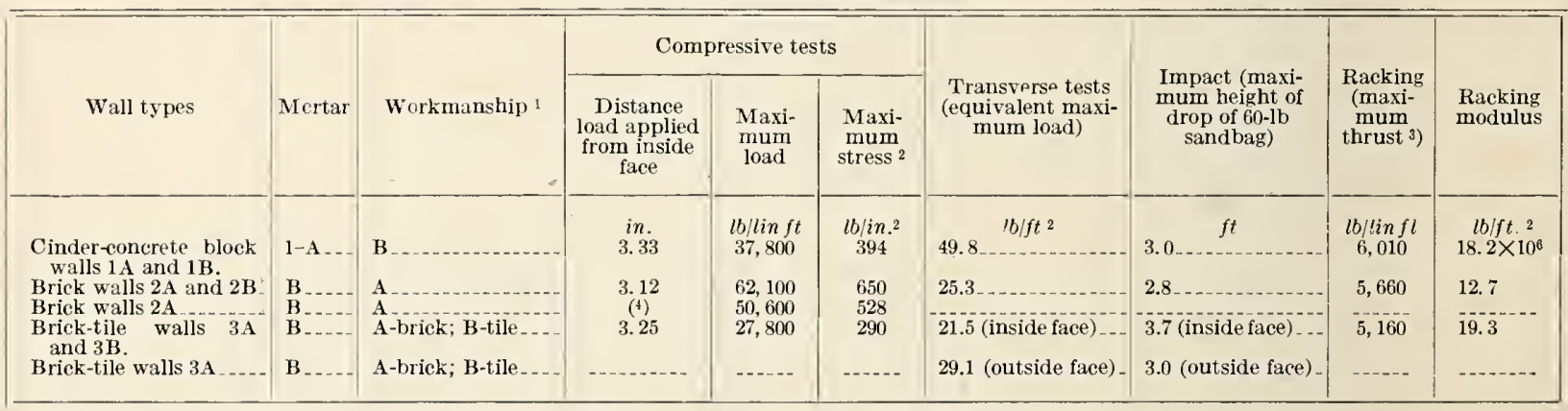

1 Workmanship A, superior. W'orkmanship B, commercial.

2 On net area, that is, total area less area of cavity.

3 Thrust applied near upper corner.

4 Load applied and centered on back wythe only.

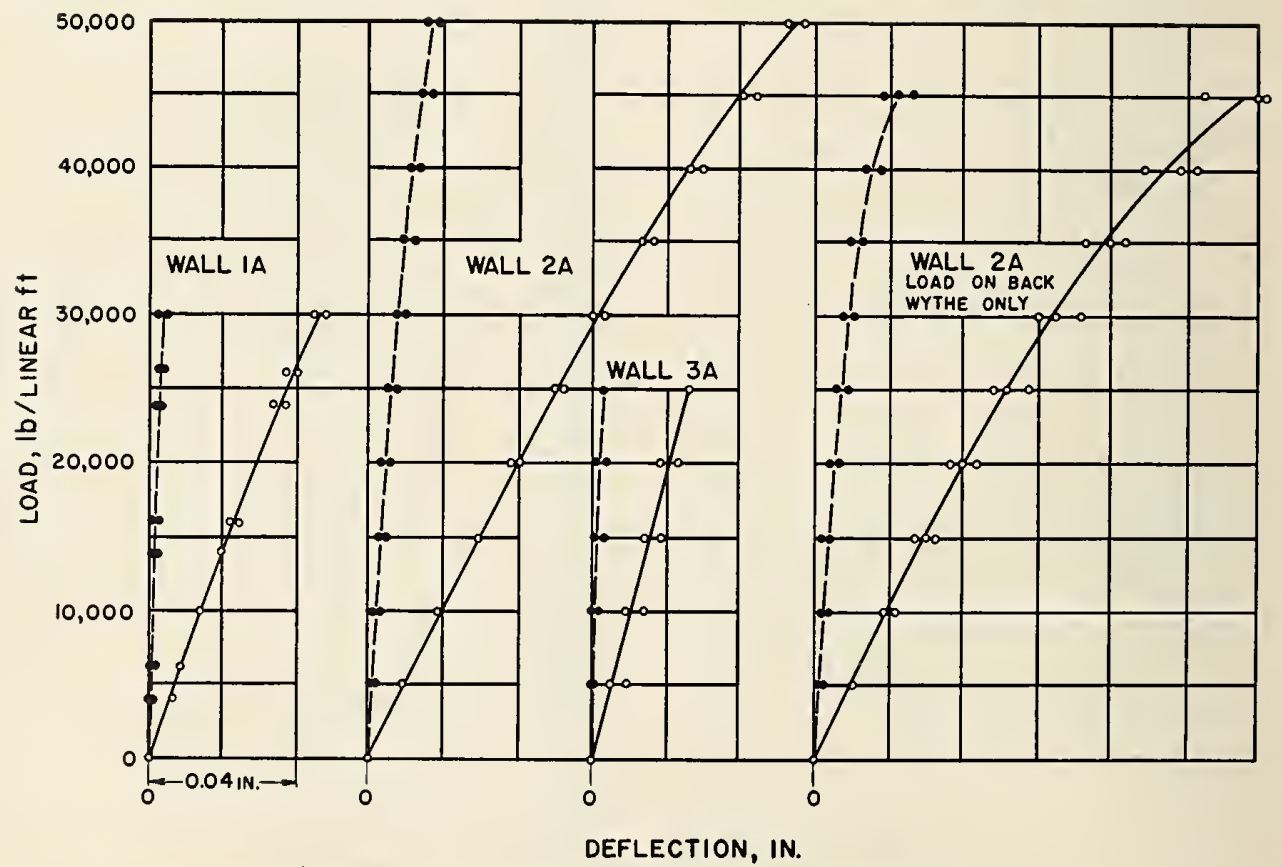

FIGURE 6. Wall shortening under compressive loads.

Opening circles represent shortenings, closed circles sets after removal of the corresponding load. Wall $1 \mathrm{~A}$, concrete-block cavity wall; wall $2 \mathrm{~A}$, brick cavity wall; wall $3 \mathrm{~A}$, brick-tile cavity wall. 


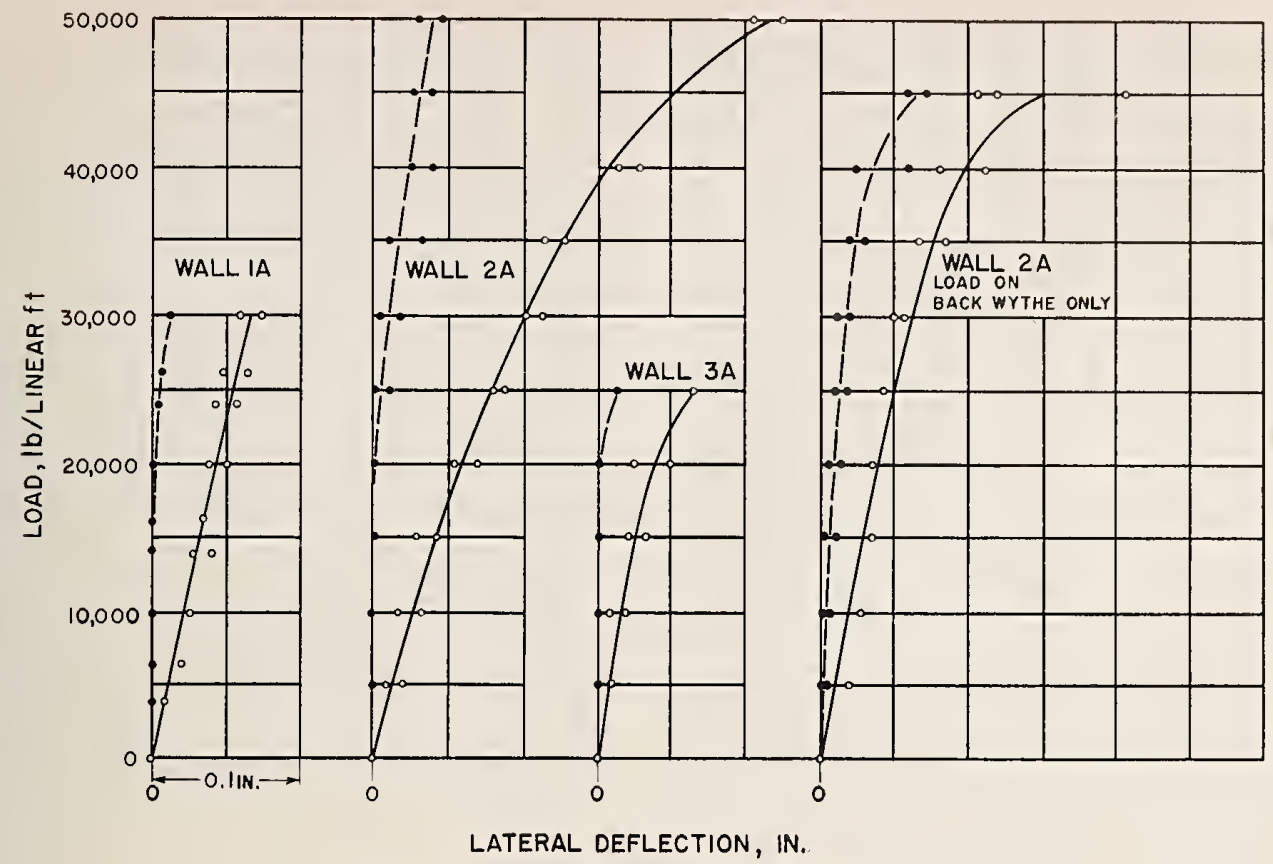

Figure 7. Lateral wall deflections under compressive loads.

Open cireles represent lateral deflections, elosed eireles lateral sets after the removal of the eorresponding load. Wall $1 \mathrm{~A}$, eoncrete-bloek cavity wall; wall $2 \mathrm{~A}$, hrick eavity wall; wall $3 \mathrm{~A}$, brick-tile.

joint in the back wythe at about two-thirds the height. The load at failure of the brick cavity walls loaded on one wythe only averaged 80 percent of the load at failure of the walls loaded on both wythes. Each of the brick-tile cavity-wall specimens failed by breaking of the tile in the upper two or three courses; no failure of the brick facing was observed.

\subsection{Transverse Load}

Transverse load tests were made with the wall in a vertical position. Two equal loads were applied, each along horizontal lines at one-quarter of the span from the supports toward the middle of the span. The wall rested against a roller near the top and another near the bottom, separated by a span of $7 \mathrm{ft} 6 \mathrm{in}$; the loading rollers were thus $3 \mathrm{ft} 9 \mathrm{in}$. apart on the loaded wythe.

A wall under transverse load is shown in figure 8. The results of the transverse load tests are presented in table 5 and the lateral deflections in figure 9

Each of the concrete-block cavity walls failed by rupture of the bond between the blocks and the mortar in both the face and the back wythes at bed joints, usually between the loading rollers. In the brick cavity walls, the bond failure occurred near a loading roller in both the loaded and opposite faces.

Three of the brick-tile cavity walls failed by rupture of the brick-mortar bond at midheight in the facing and by rupture of the bond between the

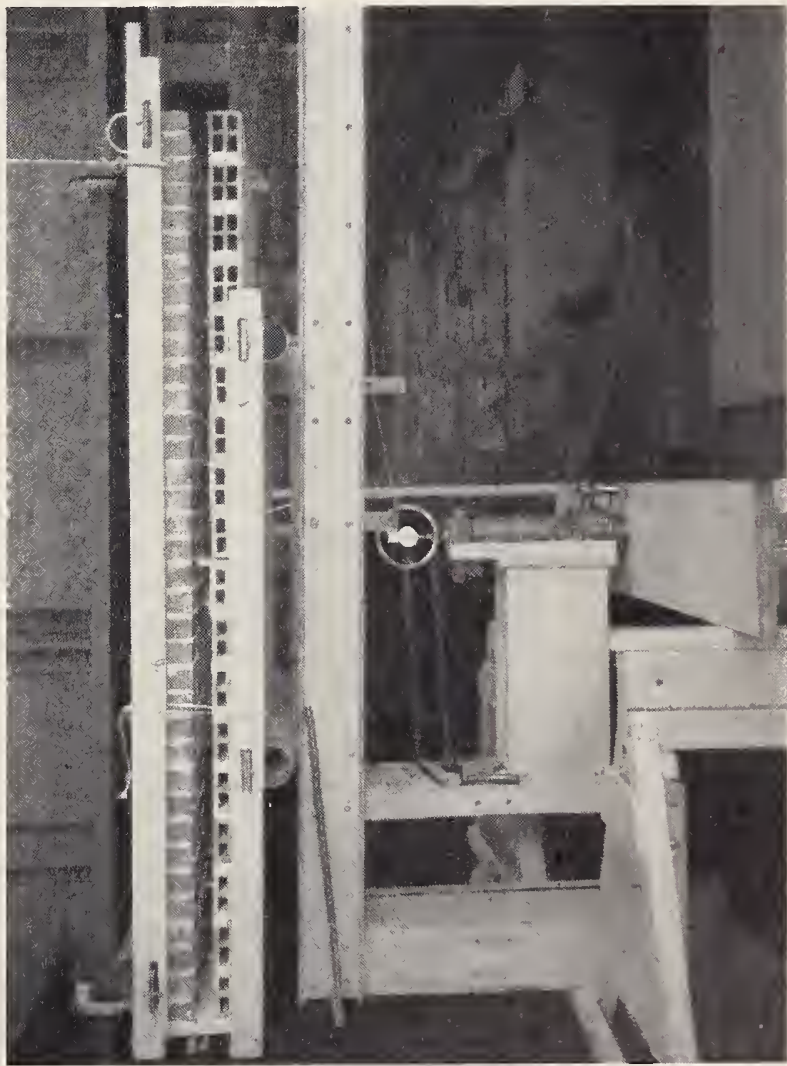

Figure 8. Brick-tile cavity wall under transverse load. Loading rollers at quarter span are shown to the right of the wall. 


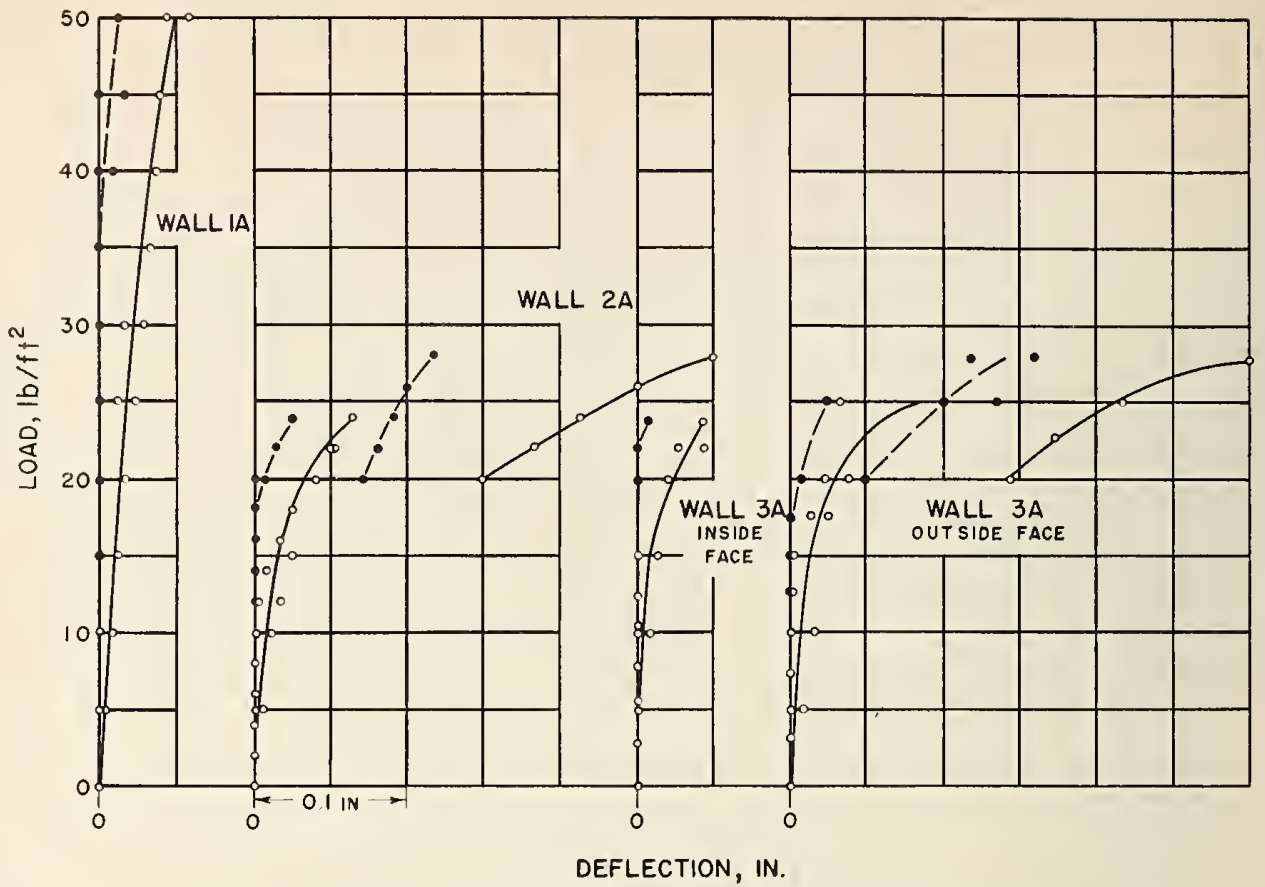

Figure 9. Wall deflection under transverse load.

Open circles represent deflections, closed circles sets after removal of the corresponding load. Wall 1A, concreteblock cavity wall; wall $2 \AA$, brick cavity wall, wall $3 \mathrm{~A}$, brick-tile eavity wall.

tile and the mortar at one or two bed joints at or between the loading rollers in the backing. For three other specimens, the bond between the tile and the mortar ruptured at a bed joint near midheight in the backing, the bond rupture on the brick face occurring at a bed joint between the loading rollers in the facing.

\subsection{Concentrated Load}

A concentrated load was applied through a 1-in. diameter steel disc placed against the facc of the test specimen at what was thought to be the weakest place. A wall under concentrated load is shown in figure 10 .

Only one specimen failed below the 1,000-lb load obtainable with the apparatus used. This was one of the brick cavity walls on which the load had been applied at a head joint. Failure of this specimen occurred by rupture of the bond between the brick and mortar at a bed joint below when a 646-lb load was applied.

\subsection{Impact Load}

The impact loads were applied by allowing a 60-lb sand bag to swing as a pendulum. The bag struck the wall about the midpoint between four wall ties near the center of one face of the specimen. A wall preparatory to impact is shown in figure 11 . The test results are given in table 5 .

For the three concrete-block cavity walls, bed joints near midheight in both the face and back

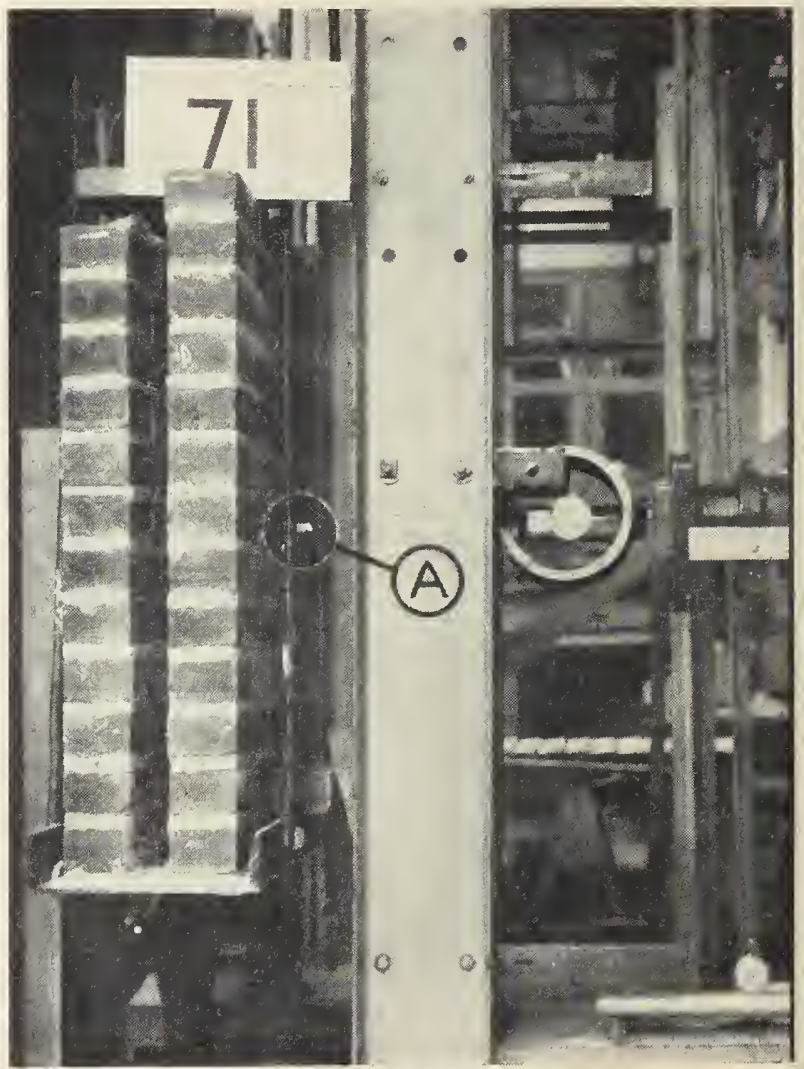

FIGURE 10. Brick cavity wall under concentrated thrust. "A" indicates the point of application of load through 1-in. disk. 


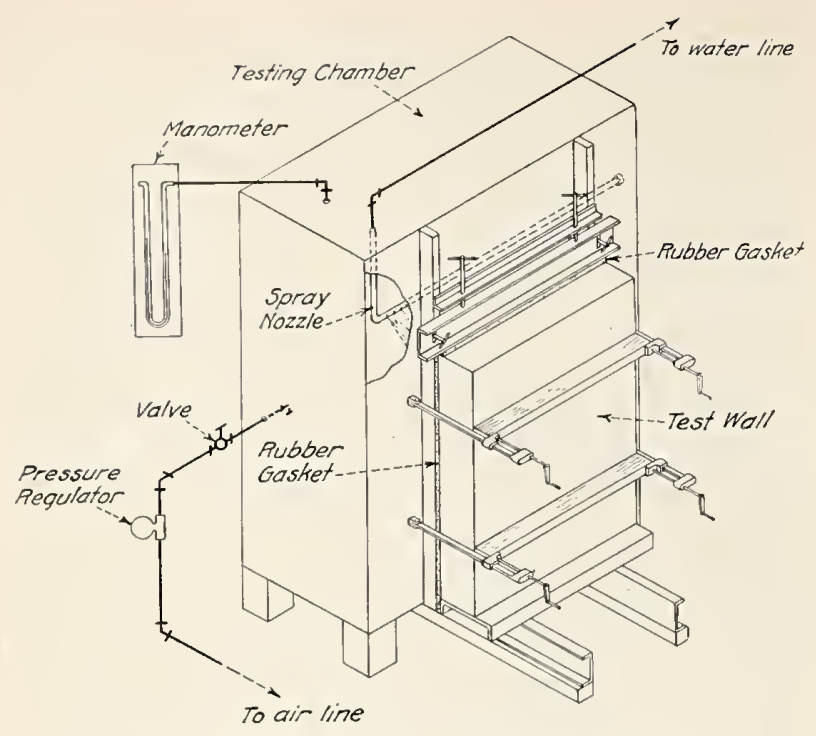

Figure 13. Water-permeability test chamber.

of one brick, three brick-tile, and one concreteblock cavity wall was examined and is reported in BMS82 [15].

\subsection{Method of Testing}

The test apparatus is shown in figure 13. The wall specimens were clamped into position against sponge-rubber gaskets so that the exposed face formed one side of a pressure chamber. Water from a perforated pipe was applied to the upper portion of the exposed face (inside the chamber), the $40-\mathrm{gal} / \mathrm{hr}$ rate being sufficient to cover the wall face with a thin sheet of flowing water. The applied air pressure maintained in the chamber was equal to that produced by a 2 -in. head of water (approximately $10 \mathrm{lb} / \mathrm{ft}^{2}$ ), about the maximum pressure difference on two faces of a wall that might be caused by a $60-\mathrm{mpl}$ wind

The air temperature in the testing room varied between $50^{\circ}$ and $75^{\circ} \mathrm{F}$. The walls were tested for not less than 1 day. As the backs of the walls had been painted with whitewash, the discoloration produced by moisture (dampness) on the back could be easily detected. The permeability test was more severe and of greater duration than the natural wind and rain storms to which most building walls are ordinarily subjected.

\subsection{Test Results}

With the exception of wall $1 \mathrm{C}$, table 4 , the backs of the walls remained dry during 1-day tests. Wall $1 \mathrm{C}$ became wet on the back above the flashing in $12 \mathrm{~min}$.

The cavities in one of the brick-tile walls, $3 \mathrm{C}$, was filled with $0.7 \mathrm{lb} / \mathrm{ft}^{2}$ of shredded redwood bark; this wall was tested both before and after the cavity was filled. With the cavity open, some moisture appeared in the region around its reversed flashings in $10 \mathrm{hr}$, but in the retest, with the cavity filled, a large damp area appeared on the back in 0.2 hr. After the tests, when the backing wythes were removed, the shredded redwood bark remained standing; water was visible at only a few points on the back of the filling, but the inside of the brick wythe was dripping wet. The filling contained about 14 percent of moisture by weight before it was placed in the wall. After the tests, it contained 50 percent of moisture at the bottom and about 20 percent at the top of the wall.

According to the Armour Research Foundation and the Structural Clay Products Institute [16], a cavity wall filled with a specially designed pouring type of fiberglas, but having no wall ties, was tested and reported to have resisted moisture penetration through the back wythe for a period of several days. Apparently there was no differential air pressure across the cavity in these tests.

\section{Heat Transfer}

In order to determine the thermal insulating value of a cavity wall as compared to that of a solid wall, and to ascertain to what degree the ventilation of a cavity wall with outdoor air affects its insulating value, heat-transfer tests were made by H. E. Robinson of the Bureau's staff on brick, brick-tile, and concrete-block cavity walls. A solid brick wall was tested for comparison purposes.

\subsection{Test Equipment and Procedure}

In the guarded hot-box heat-transfer apparatus (fig. 14), heat flowed through the specimen from the electrically heated metering and guard boxes to the cold box, which was cooled by a refrigerating machine. The guard box was used so that the space surrounding the metering box could be maintained at substantially the same temperature as the interior of the metering box. This minimized heat exchange to or from the metering box except through the specimen. To keep heat exchange through the edges of the specimen to a minimum, the top and sides were encased by an insulated wooden enclosure (not shown in fig. 14).

For testing, the specimen was placed in the apparatus, the temperature in the cold box arjusted to approximately $0^{\circ} \mathrm{F}$ and that in the metering and guard boxes to $70^{\circ} \mathrm{F}$. Air was circulated at approximately $35^{\circ} \mathrm{F}$ through the enclosure along the edges of the specimen. After a state of steady heat flow was attained, the heat transmittance of the specimen, indicated by the rate at which electric energy was supplied to the metering box, was observed.

In order to determine the effect of ventilation of the cavity on the heat-transfer properties of the brick and brick-tile cavity walls, six bricks were left out of the outside wythe, three at the third and three at the thirty-second courses, leaving openings into the cavity near both the bottom and the top of the wall. In one series of tests on the brick 


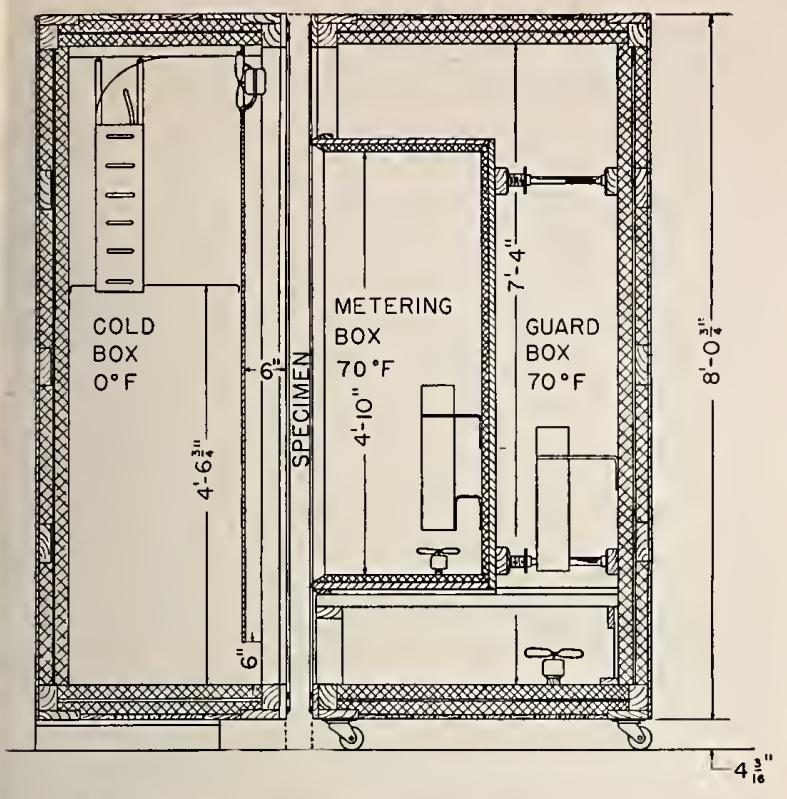

FIgURE 14. Test apparatus for heat-transfer measurements. To minimize heat exchange through the edges, the top and sides of the specimen were encased in an insulated wooden enclosure not shown in this drawing.

wall $2 \mathrm{D}$, the openings in the outside face were closed with brick chinked with sponge rubber, thereby completely sealing the cavity. In another series of tests (see table 6), the openings in the outside face were partly closed with brick and sponge rubber. Openings of $4.2-$ in. $^{2}$ area, or 1.0 in. $^{2}$ per linear foot of wall, were left at both top and bottom. In a further series of tests, the openings amounted to 7.2 in. $^{2}$ in area, or 1.7 in. $^{2}$ per linear foot of wall, and 89.0 in. $^{2}$, or 21.0 in. $^{2}$ per linear foot, respectively.

Three series of tests were run on brick-tile cavity wall $3 \mathrm{D}$, with the cavity completely sealed, with the openings between the bricks of 0.9 in. $^{2}$ per linear horizontal foot at both the top and bottom, and with openings totaling 2.5 in. $^{2}$ per linear foot at both top and bottom.

The cavity of the concrete-block wall, 1D, was not ventilated.

\subsection{Test Results}

The results of the tests on both ventilated and unventilated walls are given in table 6 . In this table, the heat-transfer coefficients of the specimens are expressed in three ways. 'The observerl thermal transmittance, $u$, is the number of Btu per hour transmitted through each square foot of the warm face of the specimen for each degree $F$ difference in temperature of the air on the two sides of the wall, with air moving at a velocity of about $2 \mathrm{mph}$ parallel to the faces on both sides of the wall. The coefficient $u$ includes the eflect of the warm-surface film coefficient $f_{i}$ and the coldsurface film coefficient $f_{0}$, the values of which for the test conditions are presented in table 6 . The film coefficients are expressed in Btu per hour per square foot of surface for each degree $F$ difference in temperature between the surface and the air.

The thermal conductance, $C$, of each of the specimens is also presented, representing the number of Btu per hour transmitted through each square foot of the warm face of the specimen for each degree $F$ difference in temperature of the two faces of the wall.

It is customary to express the heat-transfer coefficient of a building wall in terms of a selected thermal transmittance, $U$, corresponding to conditions of still air on the warm side and air moving at a velocity of $15 \mathrm{mpl}$ on the cold side of the wall. For these conditions, a value of $1.65 \mathrm{Btu} /$ (hr) $\left(\mathrm{ft}^{2}\right)\left({ }^{\circ} \mathrm{F}\right)$ is taken for the warm-surface film coefficient, $f_{i}$, and 6.00 for the cold-surface film coefficient, $f_{0}$. Values of $U$, calculated from the test results, are presented in the table for each of the unventilated walls.

When walls $2 \mathrm{D}$ and $3 \mathrm{D}$ were tested with their cavities ventilated, the symbols $u, U, C$, and $f_{0}$ were not applicable to the results as they are in ordinary cases because part of the heat was carried away by the ventilating air passing through the cavity. The quantity $u$ as recorded in table 6 was in each of these cases, therefore, the observed heat flow through the area of the specimen covered by the metering box, in Btu per hour for each

TABLE 6. Heat-transfer data

\begin{tabular}{|c|c|c|c|c|c|c|c|c|c|}
\hline \multirow[b]{3}{*}{ 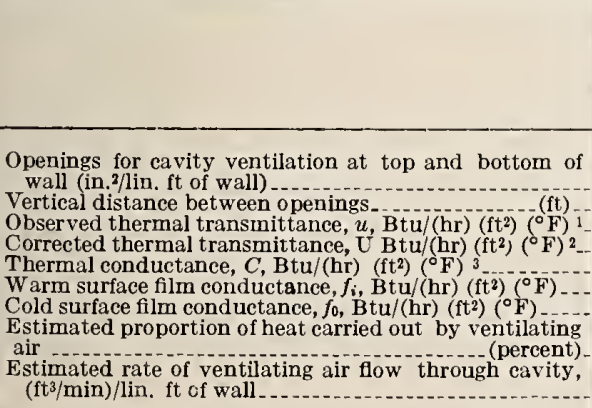 } & \multirow{3}{*}{$\begin{array}{c}\begin{array}{c}\text { Concrete- } \\
\text { block wall } \\
1 \mathrm{D} \\
\text { (eavity un- } \\
\text { ventilated) }\end{array} \\
\\
\\
0.25 \\
.27 \\
.35 \\
1.97 \\
1.51\end{array}$} & \multirow{2}{*}{$\begin{array}{c}\text { Solid } \\
\text { brick wall } \\
2 \mathrm{D}-\mathrm{S}\end{array}$} & \multicolumn{4}{|c|}{ Brick wall $2 \mathrm{D}$} & \multicolumn{3}{|c|}{ Brick-tile wall $3 \mathrm{D}$} \\
\hline & & & $\begin{array}{l}\text { Cavity un- } \\
\text { ventilated }\end{array}$ & \multicolumn{3}{|c|}{ Cavity ventilated } & $\begin{array}{l}\text { Cavity un- } \\
\text { ventilated }\end{array}$ & \multicolumn{2}{|c|}{ Cavity ventilated } \\
\hline & & $\begin{array}{r} \\
0.44 \\
.53 \\
.89 \\
1.85 \\
1.64 \\
\end{array}$ & $\begin{array}{l}0 \\
.31 \\
.35 \\
.48 \\
1.95 \\
1.64 \\
\end{array}$ & $\begin{array}{r}1.0 \\
7.2 \\
.33 \\
-.51 \\
1.96 \\
-.-- \\
13 \\
.4\end{array}$ & $\begin{array}{r}1.7 \\
7.2 \\
.34 \\
-.53 \\
1.89 \\
-. .- \\
19 \\
.6\end{array}$ & $\begin{array}{r}21.0 \\
7.2 \\
.45 \\
-.69 \\
1.94 \\
-63 \\
3.1\end{array}$ & $\begin{array}{c}0 \\
.28 \\
.31 \\
.41 \\
2.04 \\
1.46 \\
\end{array}$ & $\begin{array}{l}0.90 \\
6.8 \\
.28 \\
-.0 \\
2.07 \\
-.07 \\
. \\
.2\end{array}$ & $\begin{array}{r}2.5 \\
6.8 \\
.30 \\
-.43 \\
2.04 \\
-.- \\
17 \\
.6\end{array}$ \\
\hline
\end{tabular}

1 Between the air on the two sides of the wall, observed under test conditions.

2 Between the air on the two sides of the wall, corrected for a 15 -mph wind outside, and still air inside.

3 Between the outer surface of the outer wythe and the inner surface of the inner wythe. 
square foot and for each degree-F difference in temperature of the air on the two sides of the wall.

Solid counterparts of the brick-tile and the plastered concrete-block cavity walls were not tested, but it is estimated that their $u$ values would have been about 0.38 and $0.34 \mathrm{Btu} /(\mathrm{hr})$ $\left(\mathrm{ft}^{2}\right)\left({ }^{\circ} \mathrm{F}\right)$, respectively, and their $U$ values about 0.44 and $0.38 \mathrm{Btu} /(\mathrm{hr})\left(\mathrm{ft}^{2}\right)\left({ }^{\circ} \mathrm{F}\right)$, respectively.

As would be cxpected, the measured $u$ values of the unventilated cavity walls were considerably lower than those for their solid counterparts. 'The differences obtained in the $u$ values of the solid and sealed-cavity counterparts were due to the insulating effect of the cavity air space, the average thermal conductance of which was approximately $1.0 \mathrm{Btu} /(\mathrm{hr})\left(\mathrm{ft}^{2}\right)\left({ }^{\circ} \mathrm{F}\right)$

The $u$ values of the ventilated cavity walls increased as the size of the ventilating openings was made larger. Estimated rates of ventilating air flow through the cavity and estimates of the percentage of the heat entering the cavity that was carried out by the ventilating air are presented in table 6 . The $u$ values of the brick and the brick-tile cavity walls were increased very little by the ventilation resulting from openings at top and bottom of approximately $1.0 \mathrm{in}^{2}$ per linear foot of wall.

\section{Fire Resistance}

Seven cavity walls were subjected to standard fire exposure according to American Standards Association Specification No. A2-1934 and the American Society for Testing Materials Specification E119-47, which require that a fire exposure with standard time-temperature relation ${ }^{3}$ shall be applied to the wall. 'The specifications require that the wall must carry a continuously applied load sufficient to cause the maximum allowable working stress. The first of the following criteria to occur defines failure: (1) An average temperature rise of $250 \mathrm{deg} \mathrm{F}$ or a maximum rise of 325

3 The standard furnace temperatures are: $1,000^{\circ} \mathrm{F}$ at $5 \mathrm{~min} ; 1,300^{\circ} \mathrm{F}$ at 10 $\min ; 1,550^{\circ} \mathrm{F}$ at $30 \mathrm{~min} ; 1,700^{\circ} \mathrm{F}$ at $1 \mathrm{hr} ; 1,850^{\circ} \mathrm{F}$ at $2 \mathrm{hr} ; 2,000^{\circ} \mathrm{F}$ at $4 \mathrm{hr}$; $2,300^{\circ}$ is at $8 \mathrm{hr}$ deg $\mathrm{F}$ measured with thermocouples under asbestos pads on the unexposed side of the wall, (2) the passage of heat, gases, or flame through the specimen intense enough to ignite cotton waste, or (3) structural failure.

The walls were contained within frames that were moved into place to form one side of the furnace chamber. They were restrained within the panel frame with a constant compressive load applied vertically. One wall was tested fully restrained. None of the cavities was ventilated.

\subsection{Test Specimens}

Two of the seven walls tested were of concrete block, three of brick, and two of structural clay tile. Construction details are given in table 4, curing and loading details in table 7. A concrete block cavity wall in position for test is shown in figure 15 .

In general, a plate covering both wythes served to distribute the loads, which were applied uniformly along a line parallel to the faces of the walls. Walls $1 \mathrm{E}-1$ and $1 \mathrm{E}-2$ of hollow masonry units were loaded centrally, $1 \mathrm{E}-1$ to $80 \mathrm{lb} / \mathrm{in}^{2}{ }^{2}$ of gross area, corresponding to $100 \mathrm{lb} / \mathrm{in}^{2}{ }^{2}$ of gross less cavity area, and $1 \mathrm{E}-2$ to $80 \mathrm{lb} / \mathrm{in}^{2}{ }^{2}$ of gross less cavity area. The mortar of wall $1 \mathrm{E}-1$ as tested in cubes averaged $1,403 \mathrm{lb} / \mathrm{in}^{2}{ }^{2}$, that of wall $1 \mathrm{E}-2,2,560 \mathrm{lb} /$ in. $^{2}$ (both $1: 1: 6$ by volume). These walls were described in BMS117 [17] and BMS120 [18]. The brick walls were laid in winter, and the brick were dampened only slightly. As disclosed by examination after the tests, the mortar bond was considered good.

Wall 2E-1 was loaded centrally to $236,250 \mathrm{lb}$, or $125 \mathrm{lb} / \mathrm{in}^{2}$, of gross area, corresponding to 156 $\mathrm{lb} /$ in. $^{2}$ of gross area less cavity area. The load on wall $2 \mathrm{E}-2$ was $72,000 \mathrm{lb}$, applied $1 \frac{5}{8}$ in. off center toward the side exposed to the fire, corresponding to an average load of $80 \mathrm{lb} / \mathrm{in}^{2}{ }^{2}$ on the exposed wythe and $28 \mathrm{lb} / \mathrm{in}^{2}$ on the unexposed wythe. This load is representative of the actual load that

TABLE 7. Summary of fire-test data

Workmanship commercial, that is, head or cross joints not solidly filled

\begin{tabular}{|c|c|c|c|c|c|c|c|c|c|c|c|}
\hline \multirow{2}{*}{ Wall } & \multirow{2}{*}{ Material } & \multirow{2}{*}{$\begin{array}{c}\text { Mortar } \\
\text { (by volume) }\end{array}$} & \multirow{2}{*}{ Curing } & \multicolumn{3}{|c|}{ Loading } & \multirow{2}{*}{$\begin{array}{c}\text { Fire } \\
\text { intensity }\end{array}$} & \multicolumn{3}{|l|}{ Failure } & \multirow{2}{*}{$\begin{array}{l}\text { Maximum } \\
\text { deflection }\end{array}$} \\
\hline & & & & $\begin{array}{l}\text { Exposed } \\
\text { wythe }\end{array}$ & $\begin{array}{l}\text { Unex- } \\
\text { posed } \\
\text { wythe }\end{array}$ & $\begin{array}{l}\text { Eceen- } \\
\text { tricity }\end{array}$ & & Type & & & \\
\hline $\begin{array}{l}1 \mathrm{E}-1 \\
1 \mathrm{E}-2\end{array}$ & $\begin{array}{l}\text { Concrete block } 1 \\
\end{array}$ & $\begin{array}{l}1: 1: 6(\mathrm{~B}) \\
1: 1: 6(\mathrm{~B})\end{array}$ & $\begin{array}{c}\text { Days } \\
32 \\
30\end{array}$ & $\begin{array}{c}l b / \text { in }^{2} \\
100 \\
80\end{array}$ & $\begin{array}{c}l b / \text { in }^{2} \\
100 \\
80\end{array}$ & $\begin{array}{l}\text { in. } \\
0 \\
0\end{array}$ & $\begin{array}{l}\text { Percent } \\
101.2 \\
100\end{array}$ & $\begin{array}{l}\text { Load } \\
\text { Avg temp rise }\end{array}$ & $\begin{array}{r}h r \\
1 \\
23 \\
24\end{array}$ & $\begin{array}{c}\min \\
16 \\
45 \\
43\end{array}$ & $\begin{array}{l}\text { in. } \\
3.4 \\
1.1 \\
2.4\end{array}$ \\
\hline $\begin{array}{l}2 \mathrm{E}-1 \\
2 \mathrm{E}-2 \\
2 \mathrm{E}-3\end{array}$ & $\begin{array}{l}\text { Brick } \\
\text { do }\end{array}$ & $\begin{array}{l}1: 1: 6(\mathrm{~B}) \\
1: 1: 6(\mathrm{~B}) \\
1: 1: 6(\mathrm{~B})\end{array}$ & $\begin{array}{l}48 \\
33 \\
41\end{array}$ & $\begin{array}{c}156 \\
80 \\
(3)\end{array}$ & $\begin{array}{c}156 \\
28 \\
(3)\end{array}$ & $\begin{array}{l}0 \\
156 \\
(3)\end{array}$ & $\begin{array}{l}101 \\
100 \\
100\end{array}$ & $\begin{array}{l}\text { Load } \\
\text { Avg temp rise. }\end{array}$ & $\begin{array}{l}1 \\
5 \\
4\end{array}$ & $\begin{array}{l}16 \\
15 \\
55\end{array}$ & $\begin{array}{l}3.4 \\
3.4 \\
4.2\end{array}$ \\
\hline $\begin{array}{l}4 A-1 \\
4 A-2\end{array}$ & Hollow tile ${ }^{4}$ & $\begin{array}{l}1: 1: 4 \ldots \\
1: 1: 4\end{array}$ & $\begin{array}{l}34 \\
34\end{array}$ & $\begin{array}{l}125 \\
125\end{array}$ & $\begin{array}{l}25 \\
25\end{array}$ & $\begin{array}{l}2 \\
2\end{array}$ & $\begin{array}{l}96 \\
98\end{array}$ & _._. $\mathrm{do} \mathrm{d}_{\ldots}$ & $\begin{array}{l}4 \\
4\end{array}$ & $\begin{array}{l}7 \\
6\end{array}$ & $\begin{array}{l}1.1 \\
1.2\end{array}$ \\
\hline
\end{tabular}

1 The concrete-block walls were each divided into two separate 8 -by 11-ft sections. Wall $1 \mathrm{E}-1$ had one scetion of cinder aggregate and one section of sandand-gravel aggregate.

2 First line refers to section of wall with einder aggregate; second line to section of wall with foamed-slag aggregate.

3 Restrained from expansion in the plane of the frame.

4 Fire clay and gypsum plaster on exposed side; $1: 3$ cement plus 15 percent of lime on unexposed side. $4 \mathrm{~A}-1$ end construction; $4 \mathrm{~A}-2$ side construction. 
stance, the maximum deflection of wall $1 \mathrm{E}-1$ at $1 \mathrm{hr} 10 \mathrm{~min}$ was $3.4 \mathrm{in}$. compared to a maximum deflection of wall $1 \mathrm{E}-2$ at $4 \mathrm{hr} 40 \mathrm{~min}$ of only 2.4 min.

Wall $1 \mathrm{E}-1$ was loaded centrally to $100 \mathrm{lb} / \mathrm{in}^{2}$ of gross area less cavity area; the maximum allowable compressive load for this type of construction loaded centrally is given in reference [4], subsequently developed, as $63 \mathrm{lb} / \mathrm{in} .^{2}$, and in the tentative revision (table 1 , footnote) as $69 \mathrm{lb} / \mathrm{in}^{2}$. Wall $1 \mathrm{E}-1$ also used a weaker mortar than wall $1 \mathrm{E}-2$.

Wall $2 \mathrm{E}-1$ was loaded centrally to $156 \mathrm{lb} / \mathrm{in} .^{2}$ of gross area less cavity area; the maximum allowable compressive load for this type of construction loaded centrally is given in reference [4] as 125 $\mathrm{lb} / \mathrm{in}^{2}$ and in the tentative revision (table 1 , footnote) as $100 \mathrm{lb} / \mathrm{in}^{2}$.

The distance from the center point of the wall at midheight and the line of application of load becomes smaller as bowing takes place during fire exposure only when the load is applied eccentrically toward the exposed (back) wythe; this type of loading thus tends to be more stable than central, or uniformly distributed, loading. For example, for a centrally loaded wall and a 3-in. bow, the line of loading would be about $2 \mathrm{in}$. from the outside face of the outer wythe at the midheight of the wall. Because the most severe exposure is on the inside of a structure, and as cavity walls are used predominantly as exterior walls, eccentric loading toward the exposed face is not only favorable to a longer fire endurance but also represents the usual application.

In none of the tests did the temperature in the cavity become high enough to cause failure of the metal ties. Although these cavity walls were tested unventilated, experience with fire-endurance tests of walls with large cracks indicates that the fire endurance would not be materially affected by weep holes.

As supplemental information, the fire resistance for some unventilated cavity walls with and without plaster and with and without combustible members framed into the wall are presented in table 8.

Table 8 is adapted from National Bureau of Standards Building Materials and Structures Report BMS92 [20]. The fire-resistance ratings apply where the mortar mixes are not leaner than, 1:1:6 for brick and concrete blocks, and not leaner than 1:1:4 for structural clay tile. Loads are assumed to be applied eccentrically. Ratings were generally rounded off to a period just shorter than the test results; some of the ratings were obtained by S. H. Ingberg by interpolating or extrapolating actual test data. The effects of plaster were derived from test results and accepted formulas. The thicknesses for which endurance ratings are given are those most likely to be found in building construction. Ratings for plastered brick and concrete-block walls are for $1 / 2$-in. plaster thickness and for structural clay tile are for $5 / 8$-in. thickness inside and $3 / 4$-in. portland-cement stucco outside.

\section{Discussion and Summary}

No failure of the ties was observed in the structural tests listed in table 4 . However, tests on wall-tie assemblies, described in BMS101 [6], indicated the importance of the mortar in determining the type of the failure and under what conditions it would occur. Thus, for $1,000-\mathrm{lb} / \mathrm{in}^{2}$ mortar, a typical assembly tested in compression failed by buckling of the ties; for $270-1 \mathrm{~b} / \mathrm{in}^{2}{ }^{2}$ mortar, specimens failed by crushing of the mortar against the ends of the ties.

Assuming a tie spacing of one per $4 \frac{1}{2} \mathrm{ft}^{2}$ of wall area, any of the 6-, 8-, or 10-gage steel or copperweld Z-shaped or rectangular ties provided adequate bonding between the two wythes to maintain the relative positions of the wythes against the usual lateral loads to which such walls may be subjected. Ties in cavity walls are intended to connect the two tiers and to serve as

TABLE 8. Estimated fire resistance of cavity walls

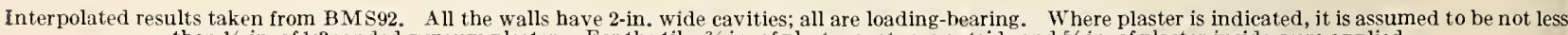
than 1,2 -in. of $1: 3$ sanded gypsum plaster. For the tile, $3 / 1$ in. of plaster or stuceo outside and $5 / 8$ in. of plaster inside were applied

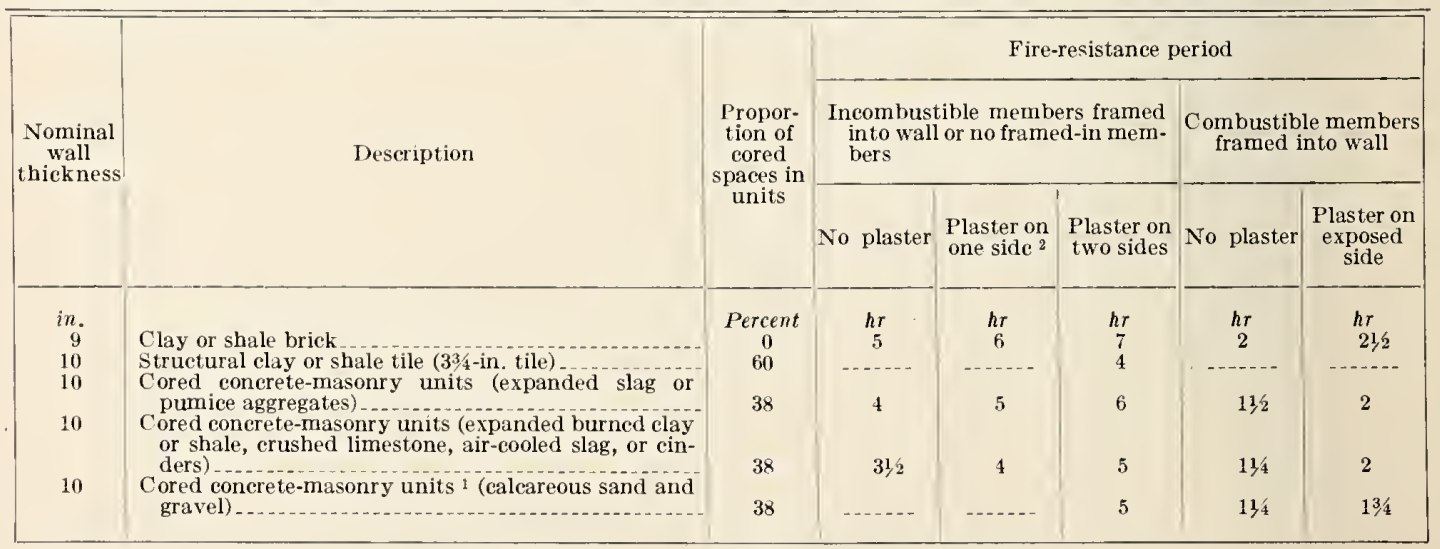

1 Coarse aggregate, 60 per cent or more calcite and dolomite. $\quad{ }^{2}$ No plaster on fire-exposed side. 
struts or tension members between them. Wall ties of the types tested did not have sufficient flexural rigidity to transmit shearing forces across the cavity. Consequently, when one wythe was subjected to a vertical load, only a small part of the load was transmitted to the other, and the two tiers did not exert common action under such loading.

Exact comparison between the structural tests on cavity walls and similar tests on solid walls $\mathrm{or}^{\circ}$ walls with continuous masonry bridges $[8,21]$ was not possible because of the difficulty of adequately reproducing mortar and workmanship and, for some of the tests, conditions of curing. For most of the compressive-strength tests, too, the distribution of the load over both wythes was not completely typical of conditions to be met in service. Rough generalizations that rould be made by conparing these test results, however, lead to the conclusion that for compressive loads with both wythes loaded, for concentrated loads, for racking loads, and for impact loads, the performance of the cavity walls was approximately equivalent to that of walls without cavities, using the same type and quantity of material; for transverse loads the performance was inferior to that of conventional walls for similar materials and workmanship. The tests indicated that cavity walls built according to accepted specifications [4] and having adequate workmanship will withstand reasonable impact and the usual floor and roof loadings of a two-story dwelling.

Results of tests indicate that while the outer wy the may be highly permeable to wind-driven rain, the proper inclusion of flashing and weep holes gives adequate protection against leakage through the inner wythe. When highly permeable concrete-masonry units were used in the facing wythe, it was necessary to apply a protective coating, consisting of portland-coment paint, to the exterior surface.

The thermal-insulating properties of a cavity wall depended upon the construction, air permeability, ventilation allowed, etc. In general, an improvement of over 25 percent in insulating properties was found for unventilated cavity walls compared with solid walls of the same material. A small amount of ventilation, not exceeding $1 \mathrm{in}^{2}$ of opening at the top and bottom per linear foot of wall, did not materially increase the thermal transmittance of the walls.

The fire resistance of unventilated cavity walls was not much different from that of walls having the same quantity of solid materials except for the load-bearing ability. In the fire tests of those walls on which the loads applied were within the limits given in "Tile Engineering" [3] and table 1 of this report, structural failure was not observed before failure by rise of temperature on the unexposed face. The condition of loading favorable to structural stability during fire occur red when the load was applied eccentrically toward the exposed (inner) wythe, a condition that would occur in most applications.
Acknowledgment is made my associates on the staff of the Building Technology Division for their helpful advice in the preparation of this paper and especially II. E. Robinson and S. IT. Ingleerg for the use of hitherto unpublished data.

\section{References}

[1] R. Fitzmaurice, Principles of modern building, I chap. III, p. 159-172 (1939). IIis Majesty's Stationery Office, London.

[2] II. C. Plummer, Brick and tile engineering (1950), Structural Clay Products Institute, Washington, D. C.

[3] H. C. Plummer, Tile engincering (1946), Structural Clay Products Institute, Washington, D. C.

[4] American Standard Building Code Requirements for Masonry (A41.1-1944). (Tentative revision, 1952.)

[5] Metal wall ties, British Standard 1243:1945, British Standards Institution, London, England.

[6] C. C. Fishburn, Strength and resistance to corrosion of ties for cavity walls, NBS Building IIaterials and Structures Report BMS101 (1943).

[7] Tentative specifications for mortar for unit masoury, ASTM Designation C270-51T, American Society for Testing Materials, Philadelphia, Pa.

[8] A. H. Stang, D. E. Parsons, and J. W. MeBurney, Compressive strength of clay brick walls, BS' 'J. Research 3, 507 (1929) RP108.

[9] D. E. Parsons, Watertightness and transverse strength of masonry walls (1939), Structural Clay Products Institute, Washington, D. C.

[10] H. L. Whittemore, J. B. Cotter, A. H. Stang, and V. B. Phelan, Strength of houses, NBS Building Materials and Structures Report BMIS109 (1948).

[11] II. I. Whittemore and A. H. Stang, Niethods of determining the structural properties of low-cost house eonstruetions, NBS Building Materials and Structures Report BNIS2 (1938).

[12] H. L. Whittemore, A. H. Stang, and D. E. Parsons, Structural properties of a concrete-block carity wall, NBS Building Materials and Structures Report BMS21 (1939).

[13] H. L. Whittemore, A. H. Stang, and D. E. Parsons, Structural properties of a brick cavity-wall construetion, NBS Building Materials and Structures Report BMS23 (1939).

[14] H. L. Whittemore, A. H. Stang, and C. C. Fishburn, Structural properties of a reinforced-brick wall construetion and a brick-tile cavity-wall construction, NBS Building Materials and Struetures Report BMS24 (1939).

[15] C. C. Fishburn, Water permeability of walls built of masonry units, NBS Building Materials and Structures Report B.IS82 (1942).

[16] Insulated cavity wall, Technieal notes of the Structural Clay Products Institute? (May 1951)

[17] H. D. Foster, E. R. Pinkston, and S. H. Ingberg, Fire resistance of walls of lightweight-aggregate concrete masonry units, NBS Building Materials and Structures Report BMS117 (1950).

[18] H. D. Foster, E. R. Pinkston, and S. H. Ingberg, Fire resistanee of walls of gravel-aggregatc concrete masonry units, NBS Building Materials and Structures Report BMS120 (1951).

[19] S. H. Ingberg and H. D. Foster, Fire resistance of hollow load-bearing walls, BS J. Research 2 (1929) RP37.

[20] Fire-resistance elassifications of building constructions, NBS Building Materials and Struetures Report BMS92 (1942).

[21] H. L. Whittemore, A. H. Stang, and D. E. Parsons, Structural properties of six masonry wall constructions, NBS Building Materials and Structures Report BMS5 (1938).

Washington, December 4, 1952. 





\section{BUILDING MATERIALS AND STRUCTURES REPORTS}

[Continued from cover page II]

BMS39 Structural Properties of a Wall Construction of "Pfeifer Units" Sponsored by the Wisconsin Units Co

BMS43

BMS44

Performance Test of Floor Coverings for Use in Low-Cost Housing: Part 2

Surface Treatment of Stecl Prior to Painting

Structural Properties of Prefabricated Wood-Frame Constructions for Walls, Partitions, and Floors Sponsored by American Houses, Inc

BMS48

Structural Properties of "Precision-Built" Frame Wall and Partition Constructions Sponsored by the Homasote $\mathrm{Co}_{-}$

BMS50

BMS51

Stability of Fiber Building Boards as Determined by Accelerated Aging

Structural Properties of "Tilecrete Type A" Floor Construction Sponsored by the Tilecrete Co

BMS52

BMS53

Effect of Ceiling Insulation Upon Summer Comfort

Structural Properties of a Masonry Wall Construction of "Munlock Dry Wall Brick" Sponsored by the Munlock. Engineering $\mathrm{Co}$

BMS54

BMS55

BMS58

BMS60

Effect of Soot on the Rating of an Oil-Fired Heating Boiler -

Effects of Wetting and Drying on the Permeability of Masonry Walls

Strength of Soft-Soldered Joints in Copper Tubing

Strength, Absorption, and Resistance to Laboratory Freezing and Thawing of Building Bricks Produced in the United States .............. 30

BMS62 Structural Properties of a Precast Joist Concrete Floor Construction Sponsored by the Portland Cement Association.

BMS63

BMS65

BMS66

BMS67

BMS68

BMS69

BMS70

BMS71

BMS72

BMS73

BMS74

Moisture Condensation in Building Walls

Methods of Estimating Loads in Plumbing Systems

Plumbing Manual

Structural Properties of "Mu-Steel" Prefabricated Sheet-Steel Constructions for Walls, Partitions, Floors, and Roof, Sponsored by Herman A. Mugler

Performance Test for Floor Coverings for Use in Low-Cost Housing: Part 3

Stability of Fiber Sheathing Boards as Determined by Accelerated Aging

Asphalt-Prepared Roll Roofings and Shingles.

Fire Tests of Wood- and Metal-Framed Partitions struction Sponsored by the Homasote $\mathrm{Co}$ " Prefabricated Wood-Trame Wall Con-

Indentation Characteristics of Floor Coverings

Structural and Heat-Transfer Properties of "U. S. S. Panelbilt" Prefabricated SheetSteel Constructions for Walls, Partitions, and Roofs Sponsored by the Tennessee Coal, Iron \& Railroad Co

BMS76

BMS77

BMS78

Effect of Outdoor Exposure on the Water Permeability of Masonry Walls.

Properties and Performance of Fiber Tile Boards Constructions.

Water-Distributing Systems for Buildings.

Performance Test of Floor Coverings for Use in Low-Cost Housing: Part 4

Field Inspectors' Check List for Building Constructions (cloth cover, $5 \times 71 / 2$ inches) ..-

Water Permeability of Walls Built of Masonry Units

Strength of Sleeve Joints in Copper Tubing Made With Various Lead-Base Solders...

Survey of Roofing Materials in the South Central States Temperature

BMS80

BMS82

BMS83

BMS84

BMS85

BMS86

BMS87

Structural, Heat-Transfer, and Water-Permeability Properties of "Speedbrik" Wall Construction Sponsored by the General Shale Products Corporation.........

A Method for Developing Specifications for Building Construction-Report of Subcommittee on Specifications of the Central Housing Committee on Research, Design, and Construction

BMS88

BMS89 Special Reference to War Housing

BMS90

BMS91

BMS92

BMS93

BMS94

BMS95

BMS96

BMS97

BMS98

BMS99

BMS100 ctural Properties of "Precision-Built, Jr." (Second Construction) Prefabricated Wood-Frame Wall Construction Sponsored by the Homasote Co.

Structural Properties of "PHC" Prefabricated Wood-Frame Constructions for Walls, Floors, and Roofs Sponsored by the PHC Housing Corporation

A Glossary of Housing Terms

Fire-Resistance Classifications of Building Constructions

Accumulation of Moisture in Walls of Frame Construction During Winter Exposure--

Water Permeability and Weathering Resistance of Stucco-Faced, Gunite-Faced, and "Knap Concrete-Unit" Walls

Tests of Cement-Water Paints and Other Waterproofings for Unit-Masonry Walls...-

Properties of a Porous Concrete of Cement and Uniform-Sized Gravel

Experimental Dry-Wall Construction With Fiber Insulating Board.............

Physical Properties of Terrazzo Aggregates "Multiple Box-Girder Plywood Panels" for

Walls, Floors, and Roofs $15 \phi$

-Out of print. 


\section{BUILDING MATERIALS AND STRUCTURES REPORTS}

[Continued from cover page III]

BMS101

BMS102

BMS103

BMS104

BMS105

BMS106

BMS107

BMS108

BMS109

BMS110

BMS111

BMS112

BMS113

BMS114

BMS115

BMS116

BMS117

BMS118

BMS119

BMS120

BMS121

BMS122

BMS123

BMS124

BMS125

BMS126

BMS127

BMS128

BMS129

BMS130

BMS131

BMS132

BMS133

BMS134

BMS135

BMS136

Strength and Resistance to Corrosion of Ties for Cavity Walls.

Painting Steel.

Measurements of Heat Losses From Slab Floors

15

Partions for Walls,

Partitions, Floors, and Roofs Sponsored by the Douglas Fir Plywood Association.

Paint Manual with particular reference to Federal Specifications _. _...

Laboratory Observations of Condensation in Wall Specimens . .

Building Code Requirements for New Dwelling Construction

Temperature Distribution in a Test Bungalow With Various Heating Devices.-..- $15 \phi$

Strength of Houses: Application of Engineering Principles to Structural Design

Paints for Exterior Masonry Walls

Performance of a Coal-Fired Boiler Converted to Oil

Properties of Some Lightweight-Aggregate Concretes With and Without an Airentraining Admixture

Fire Resistance of Structural Clay Tip Partitions-

A Study of a Basehoard Convector Heating System in a Test Bungalow

Preparation and Revision of Building Codes

Fire Resistance of Walls of Lightweight Aggregate Concrete Masonry Units

Stack Venting of Plumbing Fixtures

Wet Venting of Plumbing Fixtures

Fire Resistance of Walls of Gravel-Aggregate Concrete Masonry Units

Investigation of Failures of White-Coat Plasters

Physical Properties of Some Samples of Asbestos-Cement Siding

Fire-Tests of Wood-Framed Walls and Partitions With Asbestos-Cement Facings

Fire Tests of Steel Columns Protected With Siliceous Aggregate Concrete......-. 15

Stone Exposure Test Wall_-_.

The Self-Siphonage of Fixture Traps

Effect of Aging on the Soundness of Regularly Hydrated Dolomitic Lime Putties.-- $15 \phi$

Atmospheric Exposure Tests of Nailed Sheet Metal Building Materials_......- $20 \phi$

Fire Endurance of Shutters for Moving-Stairway Openings_................ $10 \phi$

Methods and Equipment for Testing Printed-Enamel Felt-Base Floor Covering

Fire Tests of Gunite Slabs and Partitions

Capacities of Plumbing Stacks in Buildings

Live Loads on Floors in Buildings

Fire Resistance of Concrete Floors

Fire Tests of Steel Columns Encased With Gypsum Lath and Plaster.

Properties of Cavity Walls ...

"Out of print. 